\title{
7. CALCAREOUS NANNOFOSSILS RECOVERED BY LEG 114 IN THE SUBANTARCTIC SOUTH ATLANTIC OCEAN ${ }^{1}$
}

\author{
Jason A. Crux ${ }^{2}$
}

\begin{abstract}
Ocean Drilling Program (ODP) Leg 114 recovered nannofossil-bearing sediments from seven sites in the high latitudes of the South Atlantic Ocean.

Cretaceous sections were recovered from Sites 698 and 700, located on the Northeast Georgia Rise and its lower flanks, respectively. These contain distinctive high-latitude nannofossil floras similar to those from high-latitude areas of the Northern Hemisphere. Most of the biostratigraphic datums used to date the upper Campanian to Maestrichtian interval appear to lie at approximately the same level in both hemispheres. The FAD of Nephrolithus frequens is confirmed to be diachronous with an earlier occurrence in high latitudes. The LAD of Monomarginatus primus $\mathrm{n}$. sp. also appears to be diachronous with a later LAD in the high latitudes of the Southern Hemisphere.

Fossiliferous Paleocene to lowermost Miocene sediments were recovered at all seven sites, from the Northeast Georgia Rise in the west to the Meteor Rise in the east. These nannofossil floras, although restricted in diversity and only poorly preserved, are sufficiently distinctive to allow the recognition of 19 zones and three subzones, which are used to date and correlate the cores recovered. Only Site 704 on the Meteor Rise yielded a substantial section of Miocene to Quaternary nannofossil-rich sediments. The nannofossil floras of this section are of very low diversity, with usually fewer than eight species present.

Some stratigraphic ranges of important biostratigraphic datum species are observed to be different in the high-latitude sections from those recorded from low-latitude areas. The LAD of Reticulofenestra bisecta, when calibrated by magnetostratigraphy, appears to occur earlier in Hole 699A (within Chron C6CR) than in Hole 703A and possibly Hole 704B and in other published accounts of lower latitude sites in the South Atlantic. The FAD of Nannotetrina fulgens/N. cristata appears to occur later in Hole 702B (Chron C20R) than it does in other published accounts of lower latitude sites in the South Atlantic. Diachroneity is also suspected in the stratigraphic ranges of Chiasmolithus solitus and Chiasmolithus oamaruensis, although poor magnetostratigraphic results through the critical interval prevent confirmation of this.

Differences in the relative stratigraphic ranges of Isthmolithus recurvus and Cribrocentrum coenurum/C. reticulatum at Sites 699 and 703 are noted. These possibly suggest warmer surface waters on the eastern side (Site 703) of the middle to late Eocene South Atlantic than those on the western side (Site 699).

The diversities of the nannofossil floras and the presence of the warm-water genera Discoaster, Sphenolithus, Helicosphaera, and Amaurolithus reflect the changing surface water temperatures throughout the Cenozoic. Warmer periods are inferred for the late Paleocene to early middle Eocene, late middle Eocene to late Eocene, latest Oligocene to earliest Miocene, and possibly the Pliocene. Colder periods are inferred for the middle Eocene, most of the Oligocene, and the Miocene. Dramatic changes in the nannofossil floras of the Pleistocene of Site 704 are thought to reflect a rapidly changing environment.
\end{abstract}

Monomarginatus primus, a new species from the Upper Cretaceous strata of Hole $700 \mathrm{~B}$, is described.

\section{INTRODUCTION}

Leg 114 of the Ocean Drilling Program (ODP) was the fourth cruise to the South Atlantic section of the Southern Ocean. This area is important to the understanding of the evolution of global climatic, glacial, and oceanographic systems since the late Mesozoic. Changes in these systems have probably been driven by tectonic events in the high southern latitudes, which led to the thermal isolation of Antarctica and the formation of the Antarctic ice sheets (LaBrecque et al., 1987). Twelve holes were drilled at seven sites during Leg 114, with the recovery of sediments from Santonian to Holocene age.

These sites are located on the Northeast Georgia Rise (Site 698), the lower flank of the Northeast Georgia Rise in the East Georgia Basin (Sites 699 and 700), Islas Orcadas Rise (Site 702), between the Islas Orcadas Rise and the

\footnotetext{
${ }^{1}$ Ciesielski, P. F., Kristoffersen, Y., et al., 1991. Proc. ODP, Sci. Results, 114: College Station, TX (Ocean Drilling Program).
}

2 BP Exploration, 5151 San Felipe, Houston, TX 77210.
Mid-Atlantic Ridge (Site 701), and the Meteor Rise (Sites 703 and 704) (Fig. 1).

Cretaceous sediments recovered from Sites 698 and 700 include an incomplete Santonian interval unconformably overlain by uppermost Campanian to Maestrichtian strata. The Maestrichtian section from Site 700 is the most complete recovered to date from the high-latitude Southern Ocean. An incomplete Cretaceous/Tertiary boundary section was recovered from Site 700 with the boundary lying between two cores. Incomplete sections of Paleocene strata were recovered from Sites 698, 699, 700, and 702. Almost complete Eocene sedimentary records were recovered from Sites 699, 702, and 703, with partial records from Sites 698 and 701. Thick Oligocene to lowermost Miocene nannofossil-bearing sequences were recovered from Sites 699 and 703, and lower Oligocene to lowermost Miocene strata were recovered from Site 704. Site 701 penetrated a thick Oligocene section but this did not contain in-situ nannofossils.

Most of the Miocene to Quaternary sediments recovered are barren of nannofossils, as a result of their deposition below the carbonate compensation depth (CCD). The exception was the sediments from Site 704, which contain a distinctive high-latitude nannofossil record from the Oligocene to 


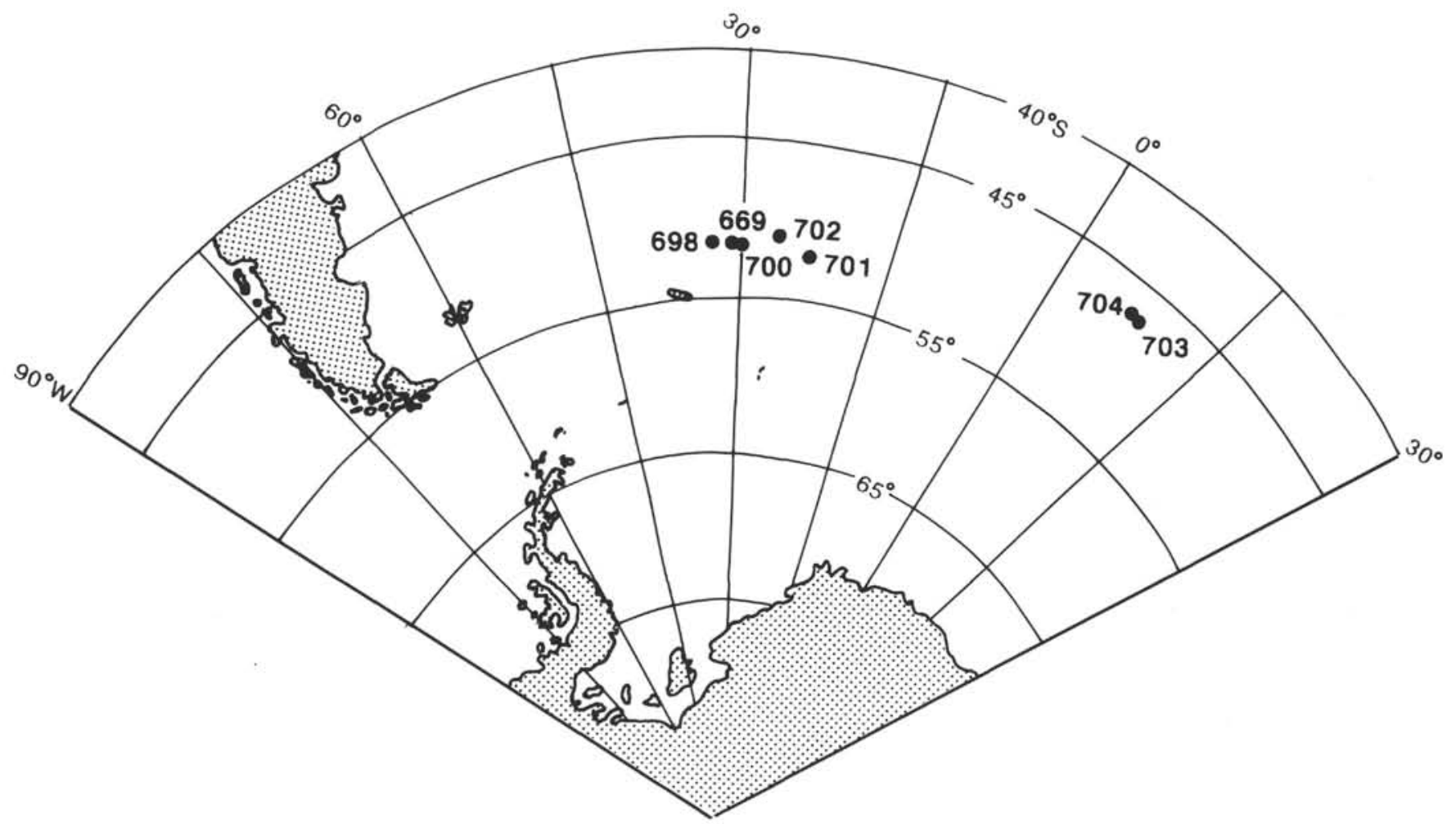

Figure 1. Site locations, ODP Leg 114.

Holocene, with only short hiatuses in the middle to upper Miocene and ?upper Pliocene. The recovered sedimentary records provide the greatest stratigraphic representation of the Upper Cretaceous to Cenozoic ever recovered from the Southern Ocean.

The aims of the present study are twofold. First, to construct a reliable biostratigraphic framework and to subdivide the fossiliferous sections penetrated using nannofossils. These subdivisions allow precise correlation of the cores recovered and help provide, together with other fossil groups and magnetostratigraphy, a chronostratigraphic framework within which sedimentologic, geochemical, and other studies can be set. The biostratigraphic zonation proposed in the present study is directly applicable to the sediments recovered. It is also possible to use the zonation to correlate with other sections from previous cruises to this area and lower latitudes.

The second aim of this study is to observe the biogeographic distribution of calcareous nannofossils in these high southern latitudes. Comparisons are made with the Cretaceous nannofossil floras of the Northern Hemisphere highlatitude areas. The presence and absence of Cenozoic lowlatitude/warm-water nannofossil genera allow some observations about the changing of surface water temperatures through time. The study of high-latitude nannofossil floras is particularly interesting, because in these cold-water conditions the stratigraphic ranges of some biostratigraphic datum species are shortened or lengthened according to the temperature preferences of the living organisms. This provides us with valuable insights into the reliability of biostratigraphic data in lower latitudes.

The methods, zonation, biostratigraphy of the sites, paleoenvironment, and provincialism and taxonomy of the calcareous nannofossils recovered are presented in the subsequent sections of this chapter. The species considered are listed in the Appendix. Most of the bibliographic references for these taxa are presented by Loeblich and Tappan (1966, 1968, 1969, 1970a, 1970b, 1971, 1973), van Heck (1979a, 1979c, 1980a, 1980b, 1981a, 1981b, 1982a, 1982b), and Steinmetz (1983a, 1983b, 1984a, 1984b, 1985a, 1985b, 1986a, 1986b, 1987a, 1987b, 1988a, 1988b). Any taxa not included in these sources are listed in the references.

Detailed nannofossil distribution tables are presented for Hole 699A and the Paleocene to Cretaceous of Hole 700B in Tables 1 through 4 . These sections were chosen for more detailed study as they represent the best preserved and most complete sections recovered by ODP Leg 114. Together they form a nannofossil-bearing composite section from the lowermost Miocene to the Santonian.

\section{METHODS}

The nannofossil floras were examined with a transmittedlight microscope at magnifications between $\times 500$ and $\times 1250$. Crossed and partially crossed nicols were used routinely, and a gypsum first-order red plate was also used to identify certain species. All slides examined were smear slides, made using a toothpick and distilled water.

In constructing the range charts (Tables 1-4), the following codes were used to depict preservation of the nannofossils:

$\mathrm{G}$ = good: well preserved, with only minor signs of dissolution and/or overgrowth.

$\mathbf{M}=$ moderate: some overgrowth and/or dissolution of placoliths and discoasters.

$\mathrm{P}=$ poor: strong overgrowth of discoasters and placoliths with secondary calcite. The assemblage is slightly biased toward solution-resistant forms.

$\mathrm{VP}=$ very poor: severe overgrowth and/or dissolution. The assemblage is strongly biased toward solution-resistant forms,

$\mathrm{E}=$ etched nannofossils predominantly present. 
Table 1. Distribution of Quaternary to Eocene calcareous nannofossils, Hole 699A.

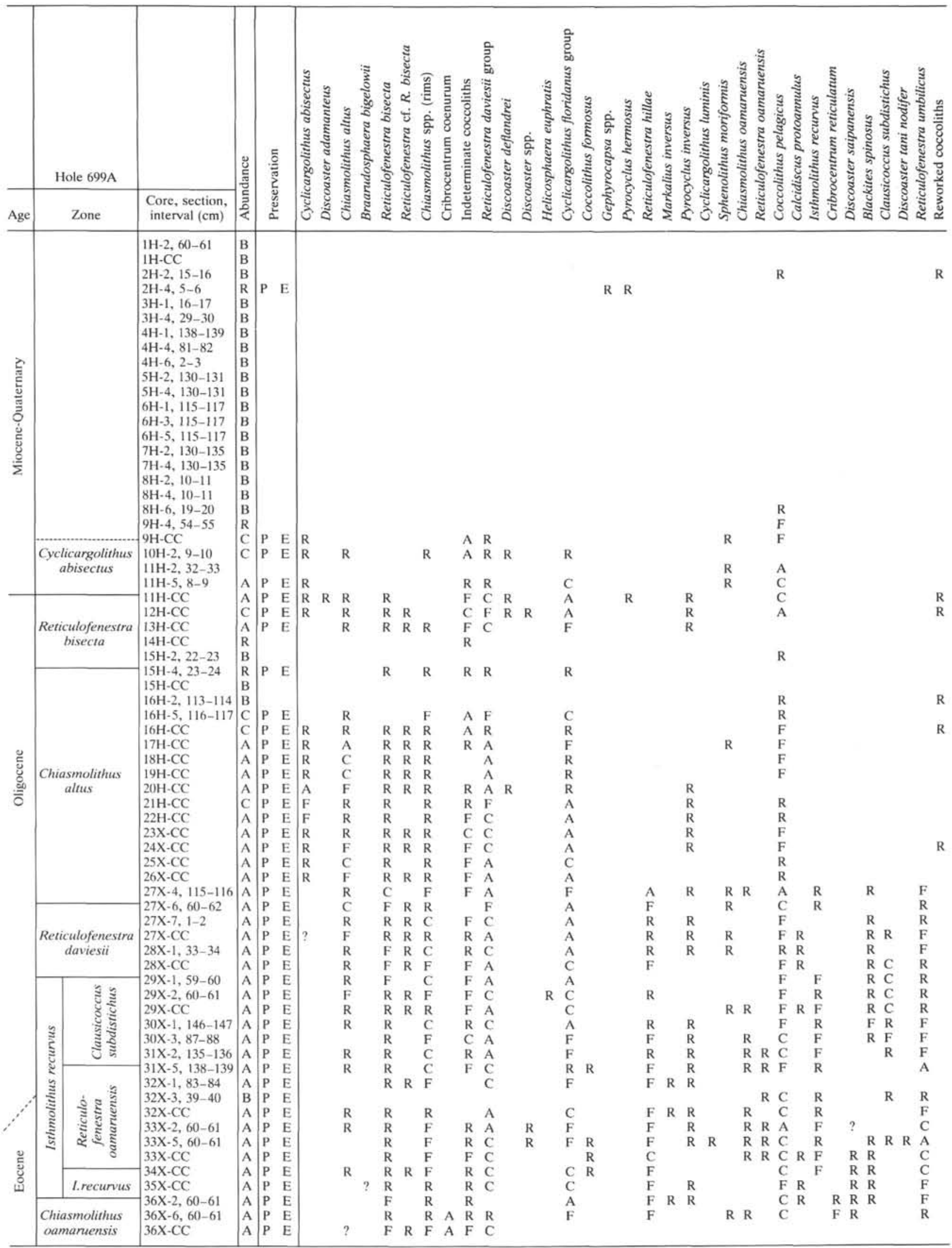

Note: $\mathrm{Abundance}$ is characterized by $\mathrm{VA}=$ very abundant, $\mathrm{A}=$ abundant, $\mathrm{C}=$ common, $\mathrm{F}=\mathrm{few}, \mathrm{R}=$ rare, $\mathrm{B}=$ barren. For preservation, $\mathrm{VP}=$ very poor, $\mathrm{P}=$ poor, $\mathrm{M}=$ moderate, $\mathrm{E}=$ etched, $\mathrm{O}=$ overgrown. 
Table 2. Distribution of Eocene to Paleocene calcareous nannofossils, Hole 699A.

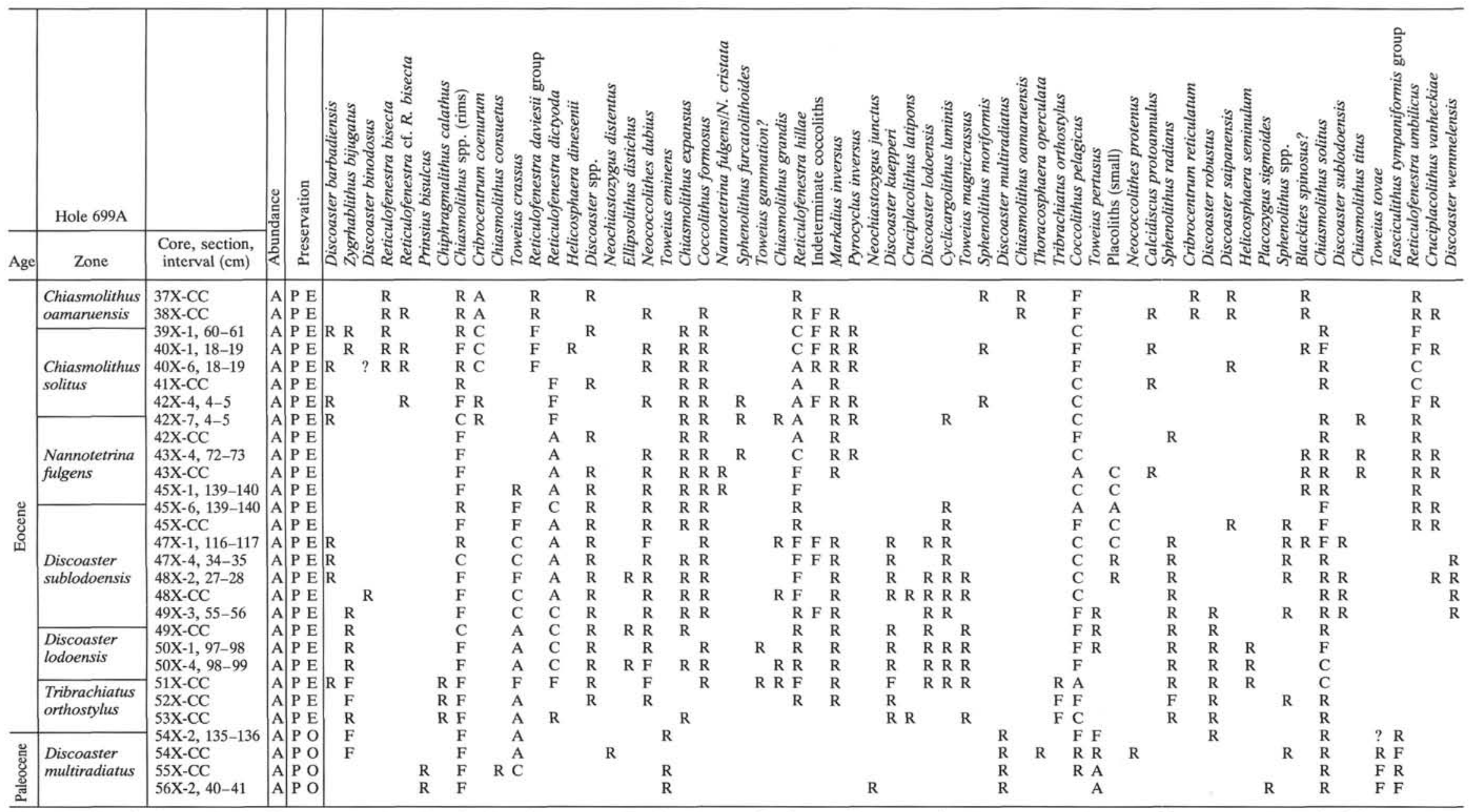

Note: Abundance is characterized by VA $=$ very abundant, $\mathrm{A}=$ abundant, $\mathrm{C}=$ common, $\mathrm{F}=$ few, $\mathrm{R}=$ rare, $\mathrm{B}=$ barren. For preservation, $\mathrm{VP}=$ very poor, $\mathrm{P}=$ poor, $\mathrm{M}=$ moderate, $\mathrm{E}=$ etched, $\mathrm{O}=$ overgrown. 
Cable 3. Distribution of Paleocene calcareous nannofossils, Hole 700B.

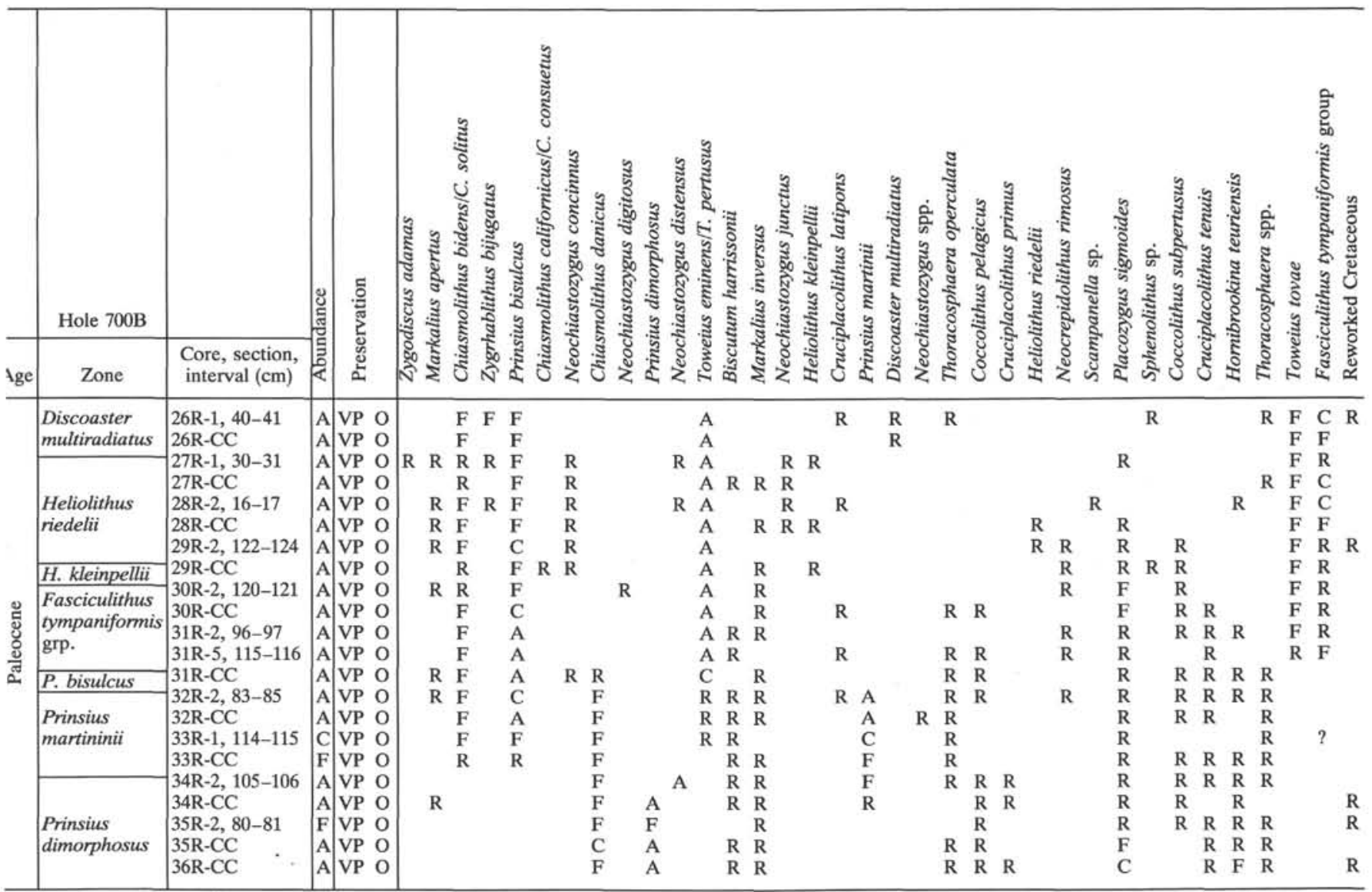

Note: Abundance is characterized by $\mathrm{VA}=$ very abundant, $\mathrm{A}=$ abundant, $\mathrm{C}=$ common, $\mathrm{F}=$ few, $\mathrm{R}=$ rare, $\mathrm{B}=$ barren. For preservation $\mathrm{VP}=$ very poor, $\mathrm{P}=$ poor, $\mathrm{M}=$ moderate, $\mathrm{E}=$ etched, $\mathrm{O}=$ overgrown.

$\mathrm{O}=$ overgrown nannofossils predominantly present.

In constructing the Cretaceous range chart (Table 4), the following procedures were adopted. The very poor preservation of the nannofossil floras and the bias of the assemblages toward solution-resistant forms made detailed counts of species meaningless. Instead, abundance estimates were made at a magnification of $\times 1250$.

$\mathrm{VA}=$ more than 5 specimens/field of view.

$\mathrm{A}=$ more than 1 specimen/field of view.

$\mathrm{C}=$ more than 1 specimen $/ 8$ fields of view.

$\mathrm{F}=$ more than 1 specimen $/ 10$ fields of view.

$\mathrm{R}=$ less than 1 specimen $/ 10$ fields of view.

In constructing the Cenozoic range charts (Tables 1-3), 200 specimens were counted at a magnification of $\times 1250$ and the following divisions were then applied to the nannofossil flora:

$$
\begin{aligned}
& \mathrm{A}=\text { more than } 30 \% . \\
& \mathrm{C}=\text { between } 30 \% \text { and } 15 \% . \\
& \mathrm{F}=\text { between } 15 \% \text { and } 3 \% . \\
& \mathrm{R}=\text { less than } 3 \% .
\end{aligned}
$$

\section{ZONATION}

\section{Mesozoic}

The most widely used Upper Cretaceous calcareous nannofossil zonal schemes (Sissingh, 1977; Roth, 1978) are only partially applicable to the sedimentary sequences of the subantarctic South Atlantic. Distinctive high-latitude nannofossil floras have been recorded from both the Southern and Northern hemispheres (Wise and Wind, 1977; Wise, 1983; Worsley and Martini, 1970; Crux, 1982; Mortimer, 1987). Many new taxa were described from the Falkland Plateau region by Wise and Wind (1977) and Wise and others in Wise (1983). Only a few of these have been recognized in similar-aged sediments from the Northern Hemisphere. A smaller number of highlatitude nannofossil species has been recognized in the Northern Hemisphere by a number of authors, including Bukry (1969), Čepek (1970), and Crux (1980, 1982). Nannofossil floras from the high latitudes of both hemispheres lack some of the zonal indices of the Sissingh (1977) scheme and other low-latitude species.

In the present study, similarities between the nannofossil floras of the high-latitude areas of both hemispheres are recognized. The experience gained in examining oil company sidewall core samples from the North Sea is used in proposing a modified zonal scheme using species that occur in the two areas. Problems remain, however, with some species appearing to have different ranges in the Northern and Southern hemispheres. In addition, direct correlation with low-latitude areas is difficult, because no area is known that has both lowand high-latitude zonal indices present. The Cretaceous zonal scheme adopted here is graphically shown in Figure 2.

\section{Lithastrinus floralis Zone}

Definition. From the first-appearance datum (FAD) of Arkhangelskiella cymbiformis to the last-appearance datum (LAD) of Lithastrinus floralis.

Author. Base, Manivit (1971); top, Wise (1983).

Age. Santonian. 
Table 4. Distribution of Cretaceous calcareous nannofossils, Hole 700B.

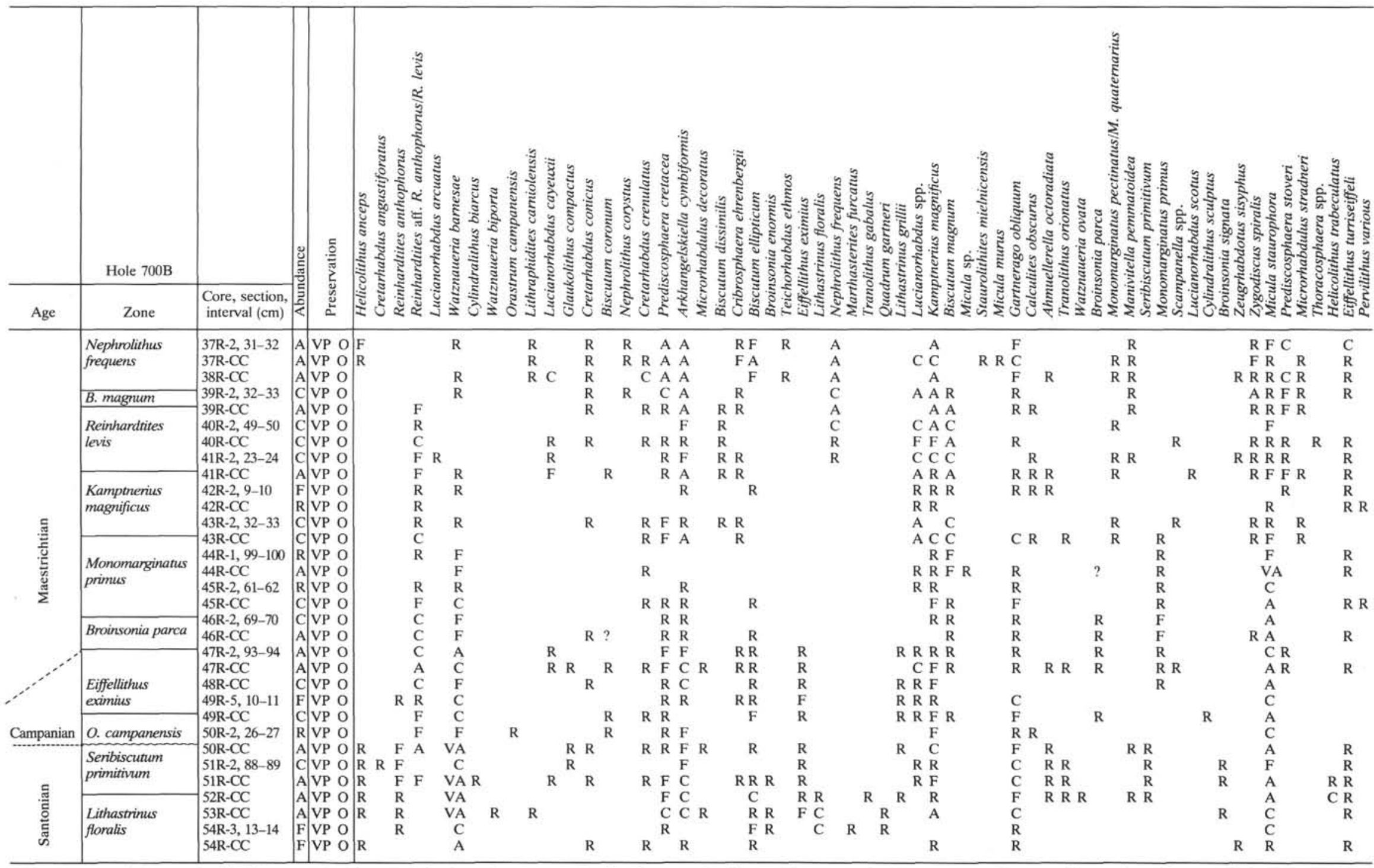

Note: Abundance is characterized by $\mathrm{VA}=$ very abundant, $\mathrm{A}=$ abundant, $\mathrm{C}=$ common, $\mathrm{F}=$ few, $\mathrm{R}=$ rare, $\mathrm{B}=$ barren. For preservation $\mathrm{VP}=\mathrm{very}$ poor, $\mathrm{P}=$ poor, $\mathrm{M}=$ moderate $, \mathrm{E}=\mathrm{etched}, \mathrm{O}=$ overgrown. 


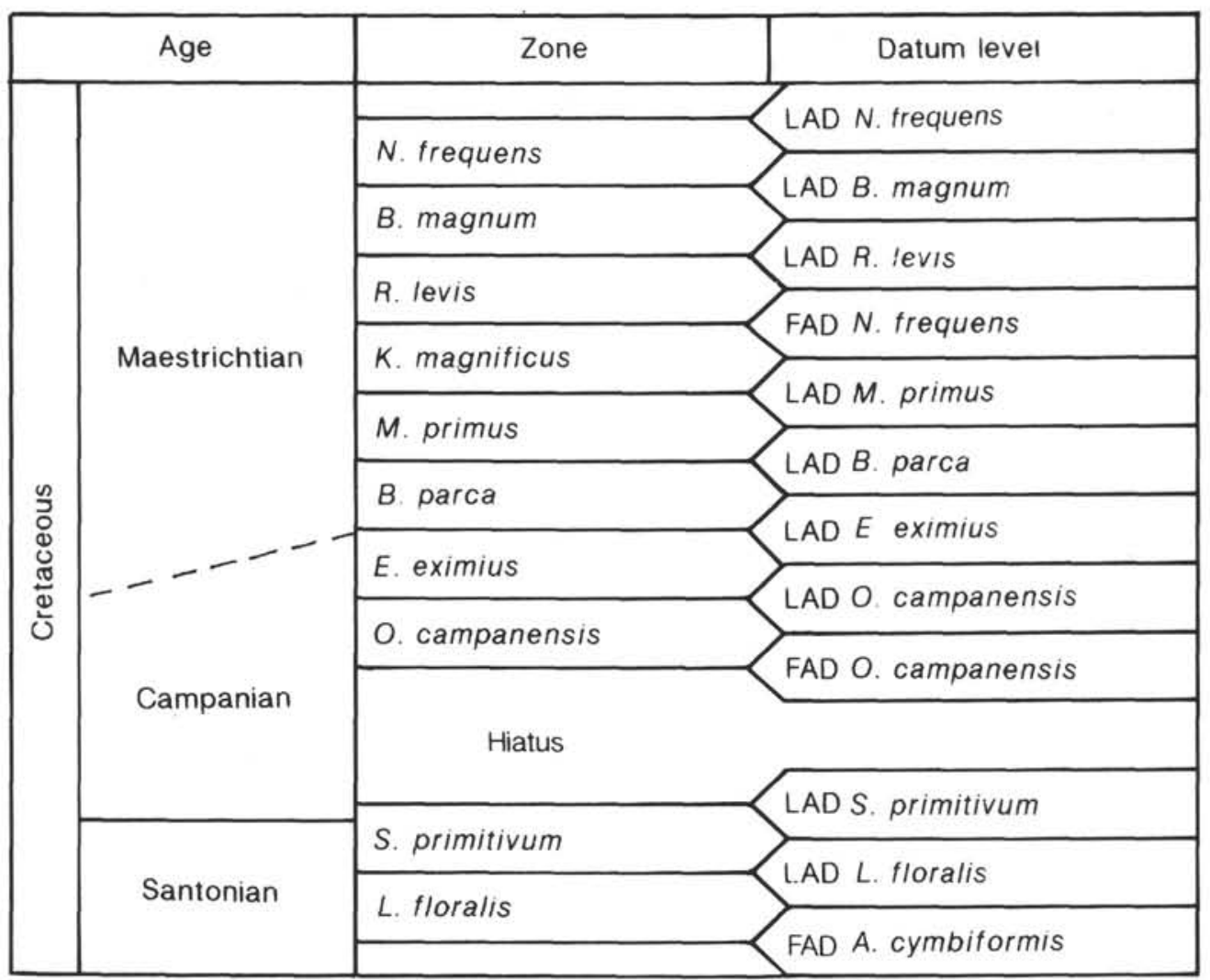

Figure 2. Cretaceous calcareous nannofossil zones used in this chapter.

Remarks. Most authors consider the LAD of L. floralis to lie within the Santonian. Bukry (1969) and Crux (1980) found the range of $L$. floralis to extend into the Campanian, although the latter recorded a considerable reduction in its abundance within the Santonian. These younger records may be a result of reworking. For my concept of A. cymbiformis, see "Taxonomy" section.

Reference section. Samples 114-700B-54R-CC to 114-700B52R-CC.

\section{Seribiscutum primitivum Zone}

Definition. From the LAD Lithastrinus floralis to the LAD of Seribiscutum primitivum.

Author. Base, Wise (1983); top, this study.

Age. Santonian-early Campanian.

Remarks. Wise (1983) recorded $S$. primitivum in sediments as young as early Campanian in the Falkland Plateau region. The last occurrence of this species at Site 700 is probably not its true extinction, as most of the Campanian is represented by a major hiatus. $S$. primitivum is reported to have preferred high-latitude/cooler surface-water areas (Wise and Wind, 1977). In the Northern Hemisphere, $S$. primitivum has not been reported above the Cenomanian (Forchheimer, 1968; Crux, 1982).

Reference section. Samples 114-700B-51R-CC to 114-700B50R-CC.

\section{Orastrum campanensis Zone}

Definition. From the FAD to the LAD of Orastrum campanensis.

Author. Base, this study; top, Mortimer (1987).

Age. Campanian, possibly extending into the earliest Maestrichtian.
Remarks. Only Sample 114-700B-50R-2, 26-27 cm, was recovered from this zone in the present study. The lower part of the zone is not present as a result of the representation of most of the Campanian by a hiatus. Although poorly represented in the present study, this zone is easily defined in the Northern Hemisphere. The first occurrence of $O$. campanensis in the Northern Hemisphere is known to occur in the Campanian (Crux, 1982). It has also been reported from Santonian sediments by Mortimer (1987), but this was from oil company cuttings and sidewall core samples that were possibly contaminated. The last occurrence of this species was taken by Mortimer (1987) to mark the Campanian/Maestrichtian boundary, although this was based on North Sea well sections in which the boundary was not precisely known.

Reference section. Sample 114-700B-50R-2, 26-27 cm.

\section{Eiffellithus eximius Zone}

Definition. From the LAD of Orastrum campanensis to the LAD of Eiffellithus eximius.

Author. Base, Mortimer (1987); top, Bukry and Bramlette (1970).

Age. Early Maestrichtian, possibly extending into the late Campanian.

Remarks. Robaszynski et al. (1985) recorded the LAD of $E$. eximius in the lower Maestrichtian of the type Maestrichtian area. The LAD of E. eximius is found regularly in North Sea well sections to lie between the LADs of $O$. campanensis and Broinsonia parca. The age assigned to this zone in the present study contradicts evidence from the foraminiferal study of Huber (this volume). Huber recorded the LAD of Globigerinelloides impensus in Core 119-700B-43X, an event that he has previously correlated with magnetostratigraphic Chron C33N at Sites 689 and 690 on the Maud Rise. This would imply 
that the LAD of E. eximius must be older than Chron $\mathrm{C} 33 \mathrm{~N}$ at Site 700 . Huber suggests that the LAD of $E$. eximius is as old as early Campanian, as it occurs in strata of reversed polarity. In this study I believe that a cosmopolitan datum such as the LAD of E. eximius, which has been widely recognized to lie near the Campanian/Maestrichtian boundary even in highlatitude areas, is more reliable than a local datum, which has yet not been extensively tested.

Further supporting evidence for a Maestrichtian to late Campanian age for the E. eximius Zone is given by the presence of Prediscosphaera stoveri, which has an FAD in the upper Campanian (Perch-Nielsen, 1985). In addition, the occurrence of Monomarginatus primus in this zone also indicates a late Campanian or younger age, as this species has an FAD recorded in the upper Campanian in the Northern Hemisphere (Crux, 1982). This latter species did, however, prefer colder water environments and may have occurred earlier in the high-latitude South Atlantic.

Reference section. Samples 114-700B-49R-CC to 114-700B47R-2, 93-94 cm.

\section{Broinsonia parca Zone}

Definition. From the LAD of Eiffellithus eximius to the LAD of Broinsonia parca.

Author. Base, Bukry and Bramlette (1970); top, Sissingh (1977).

Age. Early Maestrichtian.

Remarks. B. parca is only sporadic and rarely present toward the end of its stratigraphic range in the two holes that penetrated this zone.

Reference section. Samples 114-700B-46R-CC to 114-700B$46 \mathrm{R}-2,69-70 \mathrm{~cm}$.

\section{Monomarginatus primus Zone}

Definition. From the LAD of Broinsonia parca to the LAD of Monomarginatus primus $\mathrm{n}$. sp.

Author. Base, Sissingh (1977); top, this study.

Age. Early Maestrichtian.

Remarks. $M$. primus n. sp. (Staurolithites ellipticus sensu Crux, 1982) has been recorded only from the upper Campanian in the Northern Hemisphere. In North Sea well sections, its last occurrence is located at approximately the same level as that of $O$. campanensis. It thus appears to have a longer range in the Southern Hemisphere.

Reference section. Samples 114-700B-45R-CC to 114-700B43R-CC.

\section{Kamptnerius magnificus Zone}

Definition. From the LAD of Monomarginatus primus $\mathrm{n}$. sp. to the FAD of Nephrolithus frequens.

Author. Base, this study; top, Cepek and Hay (1969).

Age. Early? to late Maestrichtian.

Reference section. Samples 114-700B-43R-2, 32-33 cm, to 114-700B-41R-CC.

\section{Reinhardtites levis Zone}

Definition. From the FAD of Nephrolithus frequens to the LAD of Reinhardtites levis.

Author. Base, Cepek and Hay (1969); top, Sissingh (1977).

Age. Late Maestrichtian.

Remarks. Sissingh (1977) considered N. frequens and $R$. levis to be mutually exclusive and defined the Arkhangelskiella cymbiformis Zone as an interval between the LAD of $R$. levis and the FAD of $N$. frequens. In both the Northeast Georgia Rise and the Falkland Plateau areas and in the North Sea area, the FAD of Nephrolithus frequens lies stratigraphically below the LAD of Reinhardtites levis
(Wind, 1979; this study). This order of events was also noted by van Heck (1979b) in the type Maestrichtian, but she ascribed the co-occurrence of the two species to the reworking of $R$. levis into younger sediments. I consider it probable that $N$. frequens, a species known to prefer high-latitude colder water areas, has an earlier first occurrence in these latitudes, as reported by Wind (1979). The LAD of $R$. levis lies within Chron C31R.

Reference section. Samples 114-700B-41R-2, 23-24 cm, to 114-700B-39R-CC.

\section{Biscutum magnum Zone}

Definition. From the LAD of Reinhardtites levis to the LAD of Biscutum magnum.

Author. Base, Sissingh (1977); top, Wind (1979).

Age. Late Maestrichtian.

Remarks. This zone can also be recognized in the North Sea area of the Northern Hemisphere. The LAD of $B$. magnum lies within Chron C31R.

Reference section. Sample 114-700B-39R-2, 32-33 cm.

\section{Nephrolithus frequens Zone}

Definition. From the LAD of Biscutum magnum to the LAD of Nephrolithus frequens.

Author. Base, Wind (1979); top, Cepek and Hay (1969).

Age. Late Maestrichtian.

Remarks. The LAD of $N$. frequens occurs in Chron $\mathrm{C} 30 \mathrm{~N}$; its uppermost range is removed by a hiatus.

Reference section. Samples 114-700B-38R-CC to 114-700B$37 \mathrm{R}-2,31-32 \mathrm{~cm}$.

\section{Cenozoic}

The most widely used Cenozoic calcareous nannofossil zonal schemes (Martini, 1971; Bukry, 1973, 1975) are only partially applicable to the sedimentary sequences of the subantarctic South Atlantic. Progressive deterioration of the climate through the Cenozoic led to increased provincialism among the highly stenothermal calcareous nannoplankton. These algae respond quickly to changes in the thermal structure of the water masses. This is seen dramatically in the Miocene to Pleistocene of the subantarctic South Atlantic, where low diversity, endemic species, and poor preservation prevent the recognition of many biostratigraphic datums used to subdivide strata of low latitudes.

The zonation scheme employed for the Paleogene to earliest Miocene is largely based on that of Martini (1971), which in turn uses zones proposed by previous authors. Where datums used by Martini (1971) are not present, additional datums were used from the zonal schemes of Edwards (1971), Wise and Constans (1976), Romein (1979), Varol (1989), and Wise (1983). For the authorship of individual zones see Wise (1983), Perch-Nielsen (1985), and Varol (1989). Datums not previously included in these zonal schemes are the LAD of the Fasciculithus tympaniformis group and the LAD of Reticulofenestra oamaruensis. The zonal scheme adopted here is for use in the high southern latitudes. The zonation is graphically shown in Figure 3 and compared to that of Martini (1971) in Figure 4.

No formal zonal scheme is proposed for the Miocene to Quaternary intervals. I have attempted to relate the sections at Site 704 to the standard zonation scheme of Martini (1971), however, the datum species where present are so rare that the assignments are at best only approximate.

\section{Prinsius dimorphosus Zone}

Definition. From the FAD to the last abundant occurrence of Prinsius dimorphosus (76.1 to 64.6-43.8 Ma, top in Chron C27N). 


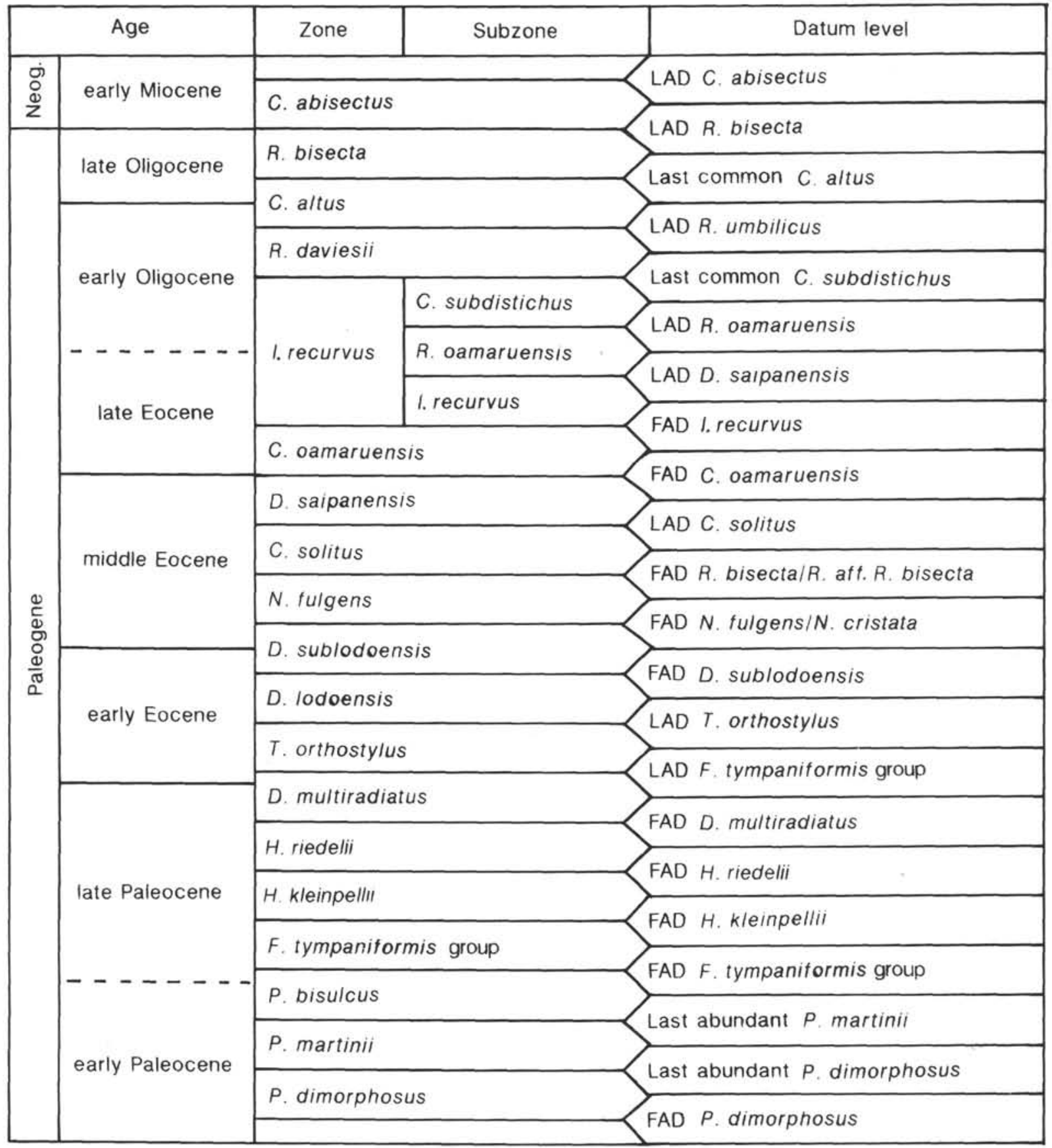

Figure 3. Paleocene to lower Miocene calcareous nannofossil zones used in this chapter.

Age. Early Paleocene.

Remarks. This zone is easily recognized in the North Sea region of the Northern Hemisphere.

Reference section. Samples 114-700B-36R-CC to 114-700B34R-2, 105-106 cm.

\section{Prinsius martinii Zone}

Definition. From the last abundant occurrence of Prinsius dimorphosus to the last abundant occurrence of Prinsius martinii (64.6-63.8 to $62.8 \mathrm{Ma}$, top in Chron C26R).

Age. Early Paleocene.

Remarks. This zone is easily recognized in the North Sea region.
Reference section. Samples 114-700B-33R-CC to 114-700B32R-2, 83-85 cm.

\section{Prinsius bisulcus Zone}

Definition. From the last abundant occurrence of Prinsius martinii to the FAD of the Fasciculithus tympaniformis group (62.7 Ma, within Chron C26R).

Age. Early to late Paleocene.

Reference section. Sample 114-700B-31R-CC.

\section{Fasciculithus tympaniformis group Zone}

Definition. From the FAD of the Fasciculithus tympaniformis group to the FAD of Heliolithus kleinpellii. 


\begin{tabular}{|c|c|c|c|c|c|c|c|c|c|}
\hline $\mathrm{Age}$ & $\begin{array}{l}\text { Martini (1971) } \\
\text { zone }\end{array}$ & Hole $698 \mathrm{~A}$ & Hole $699 \mathrm{~A}$ & Hole $700 \mathrm{~B}$ & Hole $701 \mathrm{C}$ & Hole $702 \mathrm{~B}$ & Hole $703 \mathrm{~A}$ & Hole $704 \mathrm{~B}$ & Zone, this study \\
\hline$\frac{8}{2}$ & NN 1 & & $\begin{array}{l}9 \mathrm{H}, \mathrm{CC} \\
11 \mathrm{H}-5,8-9 \mathrm{~cm}\end{array}$ & & & & $\begin{array}{l}3 \mathrm{H}-2,134-135 \mathrm{~cm} ? \\
5 \mathrm{H}-2,20-21 \mathrm{~cm}\end{array}$ & & C. abisectus \\
\hline \multirow{4}{*}{ 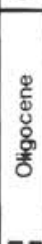 } & NP 25 & & $\begin{array}{l}11 \mathrm{H}, \mathrm{CC} \\
15 \mathrm{H}-2,22 \cdot 23 \mathrm{~cm}\end{array}$ & & & & $\begin{array}{l}5 \mathrm{H}, \mathrm{CC} \\
7 \mathrm{H} \cdot 2,10 \cdot 11 \mathrm{~cm}\end{array}$ & $64 \times, C C$ & R. bisecta \\
\hline & NP 23-24 & & $\begin{array}{l}15 \mathrm{H}-4,23-24 \mathrm{~cm} \\
27 \mathrm{X}-4,115-116 \mathrm{~cm}\end{array}$ & & & & $\begin{array}{l}7 \mathrm{H}-5,10-11 \mathrm{~cm} \\
11 \mathrm{H}, \mathrm{CC}\end{array}$ & $\begin{array}{l}65 \times, C C \\
72 \times, C C\end{array}$ & C. altus \\
\hline & NP 22 & & $\begin{array}{l}27 \times-6.60 \cdot 61 \mathrm{~cm} \\
28 \times . C C\end{array}$ & & & & $\begin{array}{l}12 \mathrm{H}-2.22-23 \mathrm{~cm} \\
12 \mathrm{H}-4.24-25 \mathrm{~cm}\end{array}$ & & R. daviesit \\
\hline & \multirow{3}{*}{ NP $19-21$} & & $\begin{array}{l}29 \times-1,59-60 \mathrm{~cm} \\
31 X-2,135-136 \mathrm{~cm}\end{array}$ & & \multirow[t]{3}{*}{$43 \times-4.34-35 \mathrm{~cm}$} & & $\begin{array}{l}12 \mathrm{H} \cdot 6.21-22 \mathrm{~cm} \\
12 \mathrm{H} . \mathrm{CC}\end{array}$ & & \multirow[b]{2}{*}{ 1. recurvus } \\
\hline-- & & & $\begin{array}{l}31 \mathrm{X}-5,138-139 \mathrm{~cm} \\
33 \mathrm{X}, \mathrm{CC}\end{array}$ & & & & $\begin{array}{l}13 \mathrm{H}-2.74-75 \mathrm{~cm} \\
15 \mathrm{H}-2.95-96 \mathrm{~cm}\end{array}$ & & \\
\hline \multirow{8}{*}{ 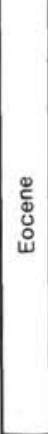 } & & & $\begin{array}{l}34 \times, C C \\
35 \times, C C \\
\end{array}$ & & & & $15 \mathrm{H} . \mathrm{CC}$ & & 1. recurvus \\
\hline & NP 18 & & $\begin{array}{l}36 \times-2,60-61 \mathrm{~cm} \\
38 \mathrm{X}, \mathrm{CC}\end{array}$ & & $\begin{array}{l}47 X, C C \\
48 X, C C \\
\end{array}$ & $\begin{array}{l}3 \mathrm{H} . \mathrm{CC} \\
5 \mathrm{X}, \mathrm{CC} \\
\end{array}$ & $\begin{array}{l}16 X-1,20-21 \mathrm{~cm} \\
20 X-2,30-31 \mathrm{~cm}\end{array}$ & & C. oamaruensis \\
\hline & NP 17 & & & & & & & & D. saipanensis \\
\hline & NP 16 & & $\begin{array}{l}39 X-1,60-61 \mathrm{~cm} \\
42 X-4,4-5 \mathrm{~cm}\end{array}$ & $\begin{array}{l}3 \mathrm{R}-1,59-60 \mathrm{~cm} \\
4 \mathrm{R}, \mathrm{CC}\end{array}$ & & $\begin{array}{l}6 X-2 . \overline{69-70} \mathrm{~cm} \\
9 \mathrm{X}, \mathrm{CC}\end{array}$ & $\begin{array}{l}20 x, C C \\
22 x, C C \\
\end{array}$ & & C. solitus \\
\hline & NP $14-16$ & & $\begin{array}{l}42 X-7,4-5 \mathrm{~cm} \\
45 X-1,139-140 \mathrm{~cm} \\
\end{array}$ & $\begin{array}{l}5 \mathrm{R} \cdot 2.70-71 \mathrm{~cm} \\
11 \mathrm{R}, \mathrm{CC}\end{array}$ & $\begin{array}{l}49 X-1,27 \cdot 28 \mathrm{~cm} \\
49 X-3,30-31 \mathrm{~cm}\end{array}$ & $\begin{array}{l}10 \times-5,20 \cdot 21 \mathrm{~cm} \\
14 X . \mathrm{CC}\end{array}$ & $\begin{array}{l}23 X-1.20-21 \mathrm{~cm} \\
30 \mathrm{C}, \mathrm{CC}\end{array}$ & & N. fulgens \\
\hline & NP 14 & $\begin{array}{l}\mathrm{R}, \mathrm{CC} \\
3 \mathrm{R}-1,20-21 \mathrm{~cm}\end{array}$ & $\begin{array}{l}45 X-6,139-140 \mathrm{~cm} \\
49 X-3,55-56 \mathrm{~cm}\end{array}$ & $\begin{array}{l}12 \mathrm{R}, \mathrm{CC} \\
16 \mathrm{R}, \mathrm{CC}\end{array}$ & $50 \times-1,75-76 \mathrm{~cm}$ & $\begin{array}{l}15 \times-2,60 \cdot 61 \mathrm{~cm} \\
21 X, \mathrm{CC}\end{array}$ & \multirow[t]{2}{*}{$33 \mathrm{X}, \mathrm{CC}$} & & D. sublodoensis \\
\hline & NP 13 & $3 \mathrm{R}, \mathrm{CC}$ & $\begin{array}{l}49 X, C C \\
50 X-4,98-99 \mathrm{~cm} \\
\end{array}$ & $\begin{array}{l}18 \mathrm{R}-1,80-81 \mathrm{~cm} \\
18 \mathrm{R}, \mathrm{CC}\end{array}$ & & $22 X-2,20-21 \mathrm{~cm}$ & & & D. lodoensis \\
\hline & NP $10-12$ & \begin{tabular}{|l|}
$4 \mathrm{R}, \mathrm{CC}$ \\
$\mathrm{BR}, \mathrm{CC}$ \\
\end{tabular} & $\begin{array}{l}51 \times, \mathrm{CC} \\
53 \times, \mathrm{CC} \\
\end{array}$ & $\begin{array}{l}20 \mathrm{R}-2,106-107 \mathrm{~cm} \\
24 \mathrm{R}, \mathrm{CC}\end{array}$ & & $\begin{array}{l}22 \times, C C \\
26 X, C C \\
\end{array}$ & & & T. orthostylus \\
\hline \multirow{7}{*}{ 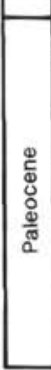 } & NP 9 & $\begin{array}{l}9 \mathrm{R}-1,52-53 \mathrm{~cm} \\
10 \mathrm{R}-1,66-67 \mathrm{~cm} \\
\end{array}$ & $\begin{array}{l}54 X-2,135-136 \mathrm{~cm} \\
56 X-2,40-41 \mathrm{~cm}\end{array}$ & $\begin{array}{l}26 \mathrm{R}-1,40-41 \mathrm{~cm} \\
26 \mathrm{R}, \mathrm{CC}\end{array}$ & & $\begin{array}{l}27 X-1,6 \cdot 7 \mathrm{~cm} \\
27 X, C C \\
\end{array}$ & & & D. multuradiatus \\
\hline & NP 8 & $\begin{array}{l}10 \mathrm{R}-2,35-36 \mathrm{~cm} \\
10 \mathrm{~A}, \mathrm{CC} \\
\end{array}$ & & $\begin{array}{l}27 \mathrm{~A}-1,30-31 \mathrm{~cm} \\
29 \mathrm{~A}-2,122-124 \mathrm{~cm}\end{array}$ & & $\begin{array}{l}28 \times \mathrm{CC} \\
30 \times, \mathrm{CC} \\
\end{array}$ & & & H. riedelii \\
\hline & NP 6-7 & $11 \mathrm{R}, \mathrm{CC}$ & & $29 \mathrm{R}, \mathrm{CC}$ & & $31 \times, C C$ & & & H. kleinpelltii \\
\hline & NP 5 & $12 \mathrm{R}, \mathrm{CC}$ & & $\begin{array}{l}30 \mathrm{R}-2,120-121 \mathrm{~cm} \\
31 \mathrm{R}-5,115-116 \mathrm{~cm} \\
\end{array}$ & & $32 \mathrm{X}, \mathrm{CC}$ & & & F.tympanitormis group \\
\hline & \multirow{3}{*}{ NP 4} & & & $31 \mathrm{R}, \mathrm{CC}$ & & & & & P. bisulcus \\
\hline & & & & $\begin{array}{l}32 \mathrm{R}-2,83-85 \mathrm{~cm} \\
33 \mathrm{R}, \mathrm{CC}\end{array}$ & & & & & P. martinii \\
\hline & & $13 \mathrm{R}, \mathrm{CC}$ & & $\begin{array}{l}34 \mathrm{R}-2,{ }_{105-106 \mathrm{~cm}} \\
36 \mathrm{R}, \mathrm{CC}^{-106}\end{array}$ & & & & & P. dimorphosus \\
\hline
\end{tabular}

Figure 4. Paleocene to lower Miocene zonal assignments for Sites 698-704. 
Age. Late Paleocene.

Remarks. For the definition of the $F$. tympaniformis group see "Taxonomy" section.

\section{Heliolithus kleinpellii Zone}

Definition. From the FAD of Heliolithus kleinpellii to the FAD of Heliolithus riedelii.

Age. Late Paleocene.

Remarks. This zone includes both the Heliolithus kleinpellii and Discoaster mohleri Zones of the Martini (1971) scheme. It is not possible to divide the zones because of the absence of D. mohleri in the sections studied. The reliability of the FAD of $H$. kleinpellii as a biostratigraphic datum is questioned by Wei and Wise (1989), who recognized some diachroneity and difficulties in differentiating it from other species of Heliolithus.

\section{Heliolithus riedelii Zone}

Definition. From the FAD of Heliolithus riedelii to the FAD of Discoaster multiradiatus.

Age. Late Paleocene.

Remarks. Both $H$. kleinpellii and $H$. riedelii are very rare in the sections studied, and thus these zonal assignments should only be regarded as approximate.

\section{Discoaster multiradiatus Zone}

Definition. From the FAD of Discoaster multiradiatus to the LAD of the Fasciculithus tympaniformis group.

Age. Late Paleocene to earliest Eocene.

Remarks. The absence of Tribrachiatus bramlettei in the sections studied does not allow recognition of the upper boundary of Martini's (1971) Discoaster multiradiatus Zone. The substitution of the LAD of the $F$. tympaniformis group for the FAD of $T$. bramlettei extends this zone into the base of the Eocene.

\section{Tribrachiatus orthostylus Zone}

Definition. From the LAD of the Fasciculithus tympaniformis group to the LAD of Tribrachiatus orthostylus.

Age. Early Eocene.

Remarks. The absence of Tribrachiatus contortus and the rare occurrence of Discoaster lodoensis in the lower part of its range in this area prevents the recognition of Martini's (1971) Tribrachiatus contortus and Discoaster binodosus Zones. These are grouped here with his overlying Tribrachiatus orthostylus Zone. Wei and Wise (1989) reported that the LAD of $T$. orthostylus was an unreliable biostratigraphic datum. It is used in the present study, however, as no other better biostratigraphic events occur to divide this interval.

\section{Discoaster lodoensis Zone}

Definition. From the LAD of Tribrachiatus orthostylus to the FAD of Discoaster sublodoensis.

Age. Early Eocene.

\section{Discoaster sublodoensis Zone}

Definition. From the FAD of Discoaster sublodoensis to the FAD of Nannotetrina fulgens/N. cristata.

Age. Early to middle Eocene.

Remarks. The FAD of $N$. fulgens/N. cristata lies within Chron C20R in Hole 702B (Ciesielski, Kristoffersen, et al., 1988), which is later than Chron C21N reported by Wei and Wise (1989) from other South Atlantic sites. This is not surprising as this species is only rarely present in all the sections studied and is probably not reaching its full stratigraphic range.

\section{Nannotetrina fulgens Zone}

Definition. From the FAD of Nannotetrina fulgens/N. cristata to the FAD of Reticulofenestra bisecta/R. aff. R. bisecta.

Age. Middle Eocene.

Remarks. The absence of Rhabdosphaera gladius in the sections studied does not allow the recognition of the upper boundary of Martini's (1971) Nannotetrina fulgens (Chiphragmalithus alatus) Zone. The FAD of $R$. bisecta used by Edwards (1971) to divide this interval appears to be a reliable datum in high-latitude sections. The FAD of $R$. bisecta/R. aff. $R$. bisecta lies within Chrons C19R-C18R in Hole 702B (Clement and Hailwood, this volume) with an age of 43.4 to $44.2 \mathrm{Ma}$.

\section{Chiasmolithus solitus Zone}

Definition. From the FAD of Reticulofenestra bisecta/R. aff. $R$. bisecta to the LAD of Chiasmolithus solitus.

Age. Middle Eocene.

Remarks. This zone is equivalent to the upper part of Martini's (1971) Discoaster tanii nodifer Zone.

Discoaster saipanensis Zone

Definition. From the LAD of Chiasmolithus solitus to the FAD of Chiasmolithus oamaruensis.

Age. Middle Eocene.

Remarks. This zone was not recognized in the present study. Its absence could be attributable to one of three causes: (1) too wide sample spacing, (2) a regional hiatus, or (3) the extension of the ranges of either or both of the two zonal indices. Perch-Nielsen (1985) and Wei and Wise (1989) reported the LAD of $C$. solitus to be diachronous, which may partially explain the absence of this zone.

\section{Chiasmolithus oamaruensis Zone}

Definition. From the FAD of Chiasmolithus oamaruensis to the FAD of Isthmolithus recurvus.

Age. Late Eocene.

\section{Isthmolithus recurvus Zone}

Definition. From the FAD of Isthmolithus recurvus to the last common occurrence of Clausicoccus subdistichus.

Age. Late Eocene to early Oligocene.

Remarks. This zone is equivalent to Martini's (1971) Isthmolithus recurvus, Sphenolithus pseudoradians, and most of the Clausicoccus (Ericsonia?) subdistichus Zones. These zones cannot be differentiated in the studied sections because of the absence and scarcity of the zonal indices. The $I$. recurvus Zone of this study is tentatively divided into the following three subzones.

\section{Isthmolithus recurvus Subzone}

Definition. From the FAD of Isthmolithus recurvus to the LAD of Discoaster saipanensis.

Age. Late Eocene.

Remarks. The rarity of D. saipanensis in the studied sections has possibly resulted in this species having an earlier LAD than in lower latitudes.

\section{Reticulofenestra oamaruensis Subzone}

Definition. From the LAD of Discoaster saipanensis to the LAD of Reticulofenestra oamaruensis.

Age. Late Eocene to early Oligocene?

Clausicoccus subdistichus Subzone

Definition. From the LAD of Reticulofenestra oamaruensis to the last common occurrence of Clausicoccus subdistichus. 


\section{J. A. CRUX}

Age. Early Oligocene.

Remarks. The last common occurrence of $C$. subdistichus is probably diachronous over large areas and changes of latitude (Wei and Wise, 1989).

\section{Reticulofenestra daviesii Zone}

Definition. From the last common occurrence of Clausicoccus subdistichus to the LAD of Reticulofenestra umbilicus.

Age. Early Oligocene.

\section{Chiasmolithus altus Zone}

Definition. From the LAD of Reticulofenestra umbilicus to the last consistent occurrence of Chiasmolithus altus.

Age. Early to late Oligocene.

\section{Reticulofenestra bisecta Zone}

Definition. From the last consistent occurrence of Chiasmolithus altus to the LAD of Reticulofenestra bisecta.

Age. Late Oligocene.

Remarks. The LAD of $R$. bisecta occurs within Chron C6CR in Hole 699A (Hailwood and Clement, this volume). This is slightly older than the level $(\mathrm{C} 6 \mathrm{~N})$ at which Wei and Wise (1989) recorded it in their South Atlantic sites.

\section{Cyclicargolithus abisectus Zone}

Definition. From the LAD of Reticulofenestra bisecta to the LAD of Cyclicargolithus abisectus.

Age. Early Miocene.

\section{SITE SUMMARIES}

The zonal assignments for the earliest Miocene to Paleogene are given in Figure 4, and those for the Cretaceous are given in Figure 5. The biostratigraphic results presented in the following are essentially the same as those presented by the shipboard scientific party in Ciesielski, Kristoffersen, et al. (1988). They are presented here in terms of the zonation scheme adopted in the present study for the Cretaceous to the earliest Miocene. This has led to more precise age assignments for the lower Paleocene to Upper Cretaceous section. The Miocene to Quaternary of Site 704 is assigned to zones of the Martini (1971) zonation scheme.

All lithostratigraphic units referred to in the site summaries are those proposed in Ciesielski, Kristoffersen, et al. (1988).

\section{Site 698}

Site $698\left(51^{\circ} 27.51^{\prime} \mathrm{S}, 33^{\circ} 05.96^{\prime} \mathrm{W}\right.$; water depth $\left.2128 \mathrm{~m}\right)$ is near the eastern edge of the shallowest part of the Northeast Georgia Rise (Fig. 1). The objectives of the site were to determine the subsidence history of the Northeast Georgia Rise, to evaluate its role as a possible major obstruction to deep-water movement during the Late Cretaceous to Paleogene, to establish its possible role as a Late Cretaceous/early Tertiary convergent boundary between the Malvinas plate and the South American plate, and to determine the temporal relationship between the subduction at the Northeast Georgia Rise and Southern Andean Orogeny.

The sedimentary sequence recovered at Site 698 consists of pelagic carbonates, grading from nannofossil ooze near the top of the hole through nannofossil chalk to limestones near the bottom of the hole. The nannofossil floras throughout Hole 698A are overgrown with secondary calcite. Most of the samples studied are fossiliferous, but the floras are generally of low diversity.

\section{Eocene}

The co-occurrence of Discoaster lodoensis and Discoaster sublodoensis in Samples 114-698A-1R-CC to 114-698A-3R-1, $20-21 \mathrm{~cm}$, indicates the presence of the D. sublodoensis Zone in this interval. Sample 114-698A-3R-CC lies between the FAD of D. sublodoensis and the LAD of Tribrachiatus orthostylus; these events define the $D$. lodoensis Zone. The occurrence of $T$. orthostylus in Samples 114-698A-4R-CC to 114-698A-8R-CC indicates the presence of the $T$. orthostylus Zone.

\section{Paleocene}

The co-occurrence of the Fasciculithus tympaniformis group and Discoaster multiradiatus in Samples 114-698A-9R-1, 52-53 $\mathrm{cm}$, to $114-698 \mathrm{~A}-10 \mathrm{R}-1,66-67 \mathrm{~cm}$, indicates the presence of the D. multiradiatus Zone. The Eocene/Paleocene boundary lies very close to the top of this zone. The absence of $D$. multiradiatus and the presence of Heliolithus riedelii in Samples 114$698 \mathrm{~A}-10 \mathrm{R}-2,35-36 \mathrm{~cm}$, to $114-698 \mathrm{~A}-10 \mathrm{R}-\mathrm{CC}$ indicates the presence of the $H$. riedelii Zone. Samples between 114-698A11R-CC and 114-698A-12R-CC continue to contain $F$. tympaniformis and are thus assigned to the Heliolithus kleinpellii to $F$. tympaniformis group Zones. The absence of $H$. kleinpellii from this interval is probably due to poor sample recovery and does not necessarily indicate a hiatus. A similar explanation for the absence of the Prinsius bisulcus and Prinsius martinii Zones is also probable. The abundant occurrence of Prinsius dimorphosus in Sample 114-698A-13R-CC indicates the presence of the $P$. dimorphosus Zone.

\section{Cretaceous}

A stratigraphic break probably occurs between Samples 114-698A-13R-CC and 114-698A-14R-1, 1-2 cm. This break separates lower Paleocene from upper Maestrichtian strata. The presence of Nephrolithus frequens between Samples 114-698A14R-1, 1-2 cm, and 114-698A-15R-CC indicates the presence of the $N$. frequens Zone. The co-occurrence of $N$. frequens and Reinhardtites levis in Samples 114-698A-16R-CC and 114-698A$17 \mathrm{R}-\mathrm{CC}$ indicates the presence of the Reinhardtites levis Zone. The failure to recognize the Biscutum magnum Zone between the $N$. frequens and $R$. levis Zones is probably due to insufficient sampling rather than the presence of a hiatus. A similar explanation is likely for the failure to recognize the Monomarginatus primus Zone below the Kamptnerius magnificus Zone at Sample 114-698A-20R-1, 48-49 cm. The presence of Broinsonia parca in Sample 114-698A-21R-CC indicates the presence of the $B$. parca Zone.

\section{Site 699}

Site $699\left(51^{\circ} 32.537^{\prime} \mathrm{S}, 30^{\circ} 40.619^{\prime} \mathrm{W}\right.$; water depth $\left.3705.5 \mathrm{~m}\right)$ is located on the northeastern slope of the Northeast Georgia Rise (Fig. 1). This site was drilled to obtain a continuously cored sequence of Late Cretaceous to Neogene age sediments, recording the history of deep-water communication between the Weddell and Georgia basins and the South Atlantic Basin. Other objectives were to document the development of the Antarctic Circumpolar Current and the southern high-latitude biosiliceous province.

The sediments recovered from Site 699 are predominantly pelagic in origin. The early Miocene to Quaternary interval (lithostratigraphic Unit I) consists of siliceous and clayey siliceous sediments. Nannofossils are recorded only from Sample 114-699A-2H-4, 5-6 cm, which contains a rare lowdiversity assemblage. Nannofossils become common to abundant at Sample 114-699A-9H-CC and below (approximately lithostratigraphic Unit II), with nannofossil siliceous oozes down to Sample 114-699A-25X-CC; below this a short interval of graded gravel (lithostratigraphic Unit III) was recovered. This probably originated uphole and fell into the hole. Below the gravel, there is a further decrease in siliceous biogenic material downhole and an increase in nannofossil chalks, which become increasingly micritic (lithostratigraphic Units IV and V). At the bottom of Hole 699A, below Section 


\begin{tabular}{|c|c|c|c|}
\hline Age & Zone & Hole $698 \mathrm{~A}$ & Hole $700 \mathrm{~B}$ \\
\hline \multirow{6}{*}{ 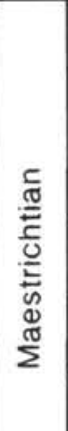 } & N. frequens & $\begin{array}{l}14 \mathrm{R}-1.1-2 \mathrm{~cm} \\
15 \mathrm{R}, \mathrm{CC}\end{array}$ & $\begin{array}{l}37 \mathrm{R}-2.31-32 \mathrm{~cm} \\
38 \mathrm{R}, \mathrm{CC}\end{array}$ \\
\hline & B. magnum & & $39 R-2,32-33 \mathrm{~cm}$ \\
\hline & R. levis & $\begin{array}{l}\text { 16R. CC } \\
\text { 17R. CC }\end{array}$ & $\begin{array}{l}39 \mathrm{R}, \mathrm{CC} \\
41 \mathrm{R}-2,23-24 \mathrm{~cm}\end{array}$ \\
\hline & $K$ magnificus & $20 \mathrm{R}-1,48-49 \mathrm{~cm}$ & $\begin{array}{l}41 \mathrm{R}, \mathrm{CC} \\
43 \mathrm{R}-2.32-33 \mathrm{~cm}\end{array}$ \\
\hline & M. primus & & $\begin{array}{l}43 \mathrm{R}, \mathrm{CC} \\
45 \mathrm{R}, \mathrm{CC} \\
\end{array}$ \\
\hline & B. parca & $21 \mathrm{R}, \mathrm{CC}$ & $\begin{array}{l}46 \mathrm{R}-2,69-70 \\
46 \mathrm{R}, \mathrm{CC}\end{array}$ \\
\hline \multirow{3}{*}{ है } & E. eximius & & $\begin{array}{l}47 \mathrm{R}-2,93-94 \mathrm{~cm} \\
49 \mathrm{R}, \mathrm{CC}\end{array}$ \\
\hline & O. campanensis & & $50 \mathrm{R}-2.26-27 \mathrm{~cm}$ \\
\hline & \multicolumn{3}{|c|}{ Hiatus } \\
\hline \multirow{2}{*}{ 心 } & S. primitivum & & $\begin{array}{l}50 R, C C \\
51 R, C C \\
\end{array}$ \\
\hline & L. floralis & & $\begin{array}{l}52 \mathrm{R}, \mathrm{CC} \\
54 \mathrm{R}, \mathrm{CC}\end{array}$ \\
\hline
\end{tabular}

Figure 5. Cretaceous zonal assignments for Sites 698-700.

114-699A-54X-1, $0 \mathrm{~cm}$, occurs a zeolite-bearing claystone with clay-bearing micritic nannofossil chalks (lithostratigraphic Unit VI). Nannofossils are poorly preserved throughout Hole 699A. Above Sample 114-699A-53X-CC, they are predominantly etched, and below this level they are predominantly overgrown with secondary calcite.

\section{Quaternary to Miocene}

Samples 114-699A-1H-2, 60-61 cm, to 114-699A-2H-2, $15-16 \mathrm{~cm}$, are barren of nannofossils. Only Sample 114-699A$2 \mathrm{H}-4,5-6 \mathrm{~cm}$, yielded a sparse nannoflora, which includes Gephyrocapsa spp., indicating a Holocene to late Pliocene age. The interval between Samples 114-699A-3H-1, 16-17 cm, and $114-699 \mathrm{~A}-9 \mathrm{H}-4,54-55 \mathrm{~cm}$, is barren of nannofossils with the exception of rare Coccolithus pelagicus in the lowest sample. The interval from Samples 114-699A-9H-CC through $114-699 \mathrm{~A}-11 \mathrm{H}-5,8-9 \mathrm{~cm}$, is assigned to the Cyclicargolithus abisectus Zone based on the presence of the nominate taxon.

\section{Oligocene}

The interval between Samples 114-699A-11H-CC and 114$699 \mathrm{~A}-15 \mathrm{H}-2,22-23 \mathrm{~cm}$, is assigned to the Reticulofenestra bisecta Zone, whereas the interval between Samples 114 $699 \mathrm{~A}-15 \mathrm{H}-4,23-24 \mathrm{~cm}$, and 114-699A-27X-4, 115-116 cm, is assigned to the Chiasmolithus altus Zone. The Reticulofenestra daviesii Zone is present between Samples 114699A-27X-6, 60-61 cm, and 114-699A-28X-CC; this is recognized by the first downhole occurrence of Reticulofenestra umbilicus. Also present in this interval is the stratigraphically significant species Isthmolithus recurvus. The presence of common Clausicoccus subdistichus in Sample 114-699A$29 \mathrm{X}-1,59-60 \mathrm{~cm}$, and below indicates the penetration of the C. subdistichus Subzone of the $I$. recurvus Zone. This is present down to Sample 114-699A-31X-2, 135-136 cm.

\section{Eocene}

The Oligocene/Eocene boundary probably lies somewhere in the Reticulofenestra oamaruensis Subzone of the $I$. recurvus Zone. The presence of this subzone is indicated between Sam- ples 114-699A-31X-5, 138-139 cm, and 114-699A-33X-CC by the presence of the nominate taxon. The interval between Samples 114-699A-34X-CC and 114-699A-35X-CC is assigned to the $I$. recurvus Subzone of the I. recurvus Zone, based on the co-occurrence of $I$. recurvus and Discoaster saipanensis.

The interval between the FAD of $I$. recurvus and the FAD of Chiasmolithus oamaruensis defines the $C$. oamaruensis Zone. This is present between Samples 114-699A-36X-2, 60-61 cm, and 114-699A-38X-CC. A possible stratigraphic break occurs between the base of this zone and the top of the underlying Chiasmolithus solitus Zone, with the D. saipanensis Zone absent. This is discussed more fully under "Paleoenvironment and Provincialism."

The $C$. solitus Zone is present between Samples 114-699A$39 \mathrm{X}-1,60-61 \mathrm{~cm}$, and 114-699A-42X-4, 4-5 cm, as indicated by the co-occurrence of $C$. solitus and Reticulofenestra bisecta. The Nannotetrina fulgens Zone is present between Samples 114-699A-42X-7, 4-5 cm, and 114-699A-45X-1, $139-140 \mathrm{~cm}$. Samples 114-699A-45X-6, $139-140 \mathrm{~cm}$, to 114 $699 \mathrm{~A}-49 \mathrm{X}-3,55-56 \mathrm{~cm}$, are assigned to the Discoaster sublodoensis Zone, which is the interval between the FAD of $N$. fulgens/Nannotetrina cristata and the FAD of D. sublodoensis. The Discoaster lodoensis Zone occurs between Samples 114-699A-49X-CC and 114-699A-50X-4, 98-99 cm. The presence of Tribrachiatus orthostylus between Samples 114-699A51X-CC and 114-699A-53X-CC indicates the presence of the $T$. orthostylus Zone.

\section{Paleocene}

The co-occurrence of $D$. multiradiatus and the Fasciculithus tympaniformis group between Samples 114-699A-54X-2, 135$136 \mathrm{~cm}$, and $114-699 \mathrm{~A}-56 \mathrm{X}-2,40-41 \mathrm{~cm}$, indicates the presence of the Discoaster multiradiatus Zone. The Eocene/Paleocene boundary lies within this zone near the top.

\section{Site 700}

Site $700\left(51^{\circ} 31.992^{\prime} \mathrm{S}, 30^{\circ} 16.697^{\prime} \mathrm{W}\right.$; water depth $\left.3601 \mathrm{~m}\right)$ is in the western region of the East Georgia Basin on the northeastern slope of the Northeast Georgia Rise. The pur- 
pose of drilling Site 700 was to reach the deeper strata and basement not achieved by drilling Hole 699A. The objective was to obtain an Upper Cretaceous-Paleogene section recording the role of the Georgia Basin as an avenue for deep-water communication between the Weddell Sea and the South Atlantic. An additional objective was to further constrain the nature, age, and subsidence history of the Northeast Georgia Rise.

The sediments recovered from Hole 700B were divided into five lithostratigraphic units: Unit I, Quaternary-upper Pliocene diatom ooze; Unit II, middle Eocene nannofossil ooze; Unit III, middle to lower Eocene nannofossil chalk that passes into micritic nannofossil chalk downhole; Unit IV, Paleocene micritic, indurated nannofossil chalk; and Unit V, lower Paleocene to Santonian micritic-nannofossil-bearing limestone that passes down into alternating micritic limestones and clay-bearing or clayey micritic limestones. These lithologic divisions are reflected in the preservation of the nannofossils. Unit I is barren of an in-situ nannofossil flora, and Units II through V contain rare to abundant nannofossil floras, most of which are very poorly preserved with considerable secondary calcite overgrowth. There is some variation within the general category of very poor preservation, with some intervals in the Upper Cretaceous section containing the solution-resistant species Micula staurophora in abundant numbers. This probably indicates considerable selective dissolution of the original flora. In contrast, there is a marked improvement in preservation of the nannofossils from Cores $114-700 \mathrm{~B}-50 \mathrm{R}$ to $114-700 \mathrm{~B}-53 \mathrm{R}$, where the increased clay content of the sediments has protected the nannofloras from the worst effects of dissolution.

\section{Quaternary to Miocene}

Sample 114-700B-1W-CC is barren of in-situ nannofossils; isolated reworked Paleogene species were recorded.

\section{Eocene}

The nannofossil floras from the interval between Samples 114-700B-3R-1, 59-60 cm, and 114-700B-4R-CC are assigned to the Chiasmolithus solitus Zone. The presence of this zone is indicated by the co-occurrence of C. solitus and Reticulofenestra bisecta. The interval between Samples 114-700B$5 \mathrm{R}-2,70-71 \mathrm{~cm}$, and $114-700 \mathrm{~B}-11 \mathrm{R}-\mathrm{CC}$ is assigned to the Nannotetrina fulgens Zone, with the nominate taxon occurring between Samples 114-700B-7R-2, 33-34 cm, and 114$700 \mathrm{~B}-11 \mathrm{R}-\mathrm{CC}$. The interval between the FAD of $N$. fulgens/N. cristata and the FAD of Discoaster sublodoensis defines the D. sublodoensis Zone between Samples 114-700B-12R-CC and 114-700B-16R-CC. The interval between Samples 114$700 \mathrm{~B}-18 \mathrm{R}-1,80-81 \mathrm{~cm}$, and $114-700 \mathrm{~B}-18 \mathrm{R}-\mathrm{CC}$ is assigned to the Discoaster lodoensis Zone, as it lies between the FAD of D. sublodoensis and the LAD of Tribrachiatus orthostylus. The interval between Samples 114-700B-20R-2, 106-107 cm, and $114-700 \mathrm{~B}-24 \mathrm{R}-\mathrm{CC}$ is assigned to the $T$. orthostylus Zone. The nominate taxon is present in all samples examined except the bottom one.

\section{Paleocene}

The co-occurrence of Discoaster multiradiatus and the Fasciculithus tympaniformis group indicates the presence of the D. multiradiatus Zone between Samples 114-700B-26R-1, $40-41 \mathrm{~cm}$, and 114-700B-26R-CC. The interval between the FAD of D. multiradiatus and the FAD of Heliolithus riedelii defines the $H$. riedelii Zone, which lies between Samples 114-700B-27R-1, 30-31 cm, and 114-700B-29R-2, 122-124 cm. Only Sample 114-700B-29R-CC contains Heliolithus kleinpellii and is assigned to the $H$. kleinpellii Zone. The interval between Samples 114-700B-30R-2, 120-121 cm, and 114$700 \mathrm{~B}-31 \mathrm{R}-5,115-116 \mathrm{~cm}$, continues to contain the $F$. tympaniformis group, but without $H$. kleinpellii, and is thus assigned to the F. tympaniformis group Zone. Only Sample 114-700B$31 \mathrm{R}-\mathrm{CC}$ lies in the interval between the FAD of the $F$. tympaniformis group and the last abundant occurrence of Prinsius martinii. It is assigned to the Prinsius bisulcus Zone. The interval between the last abundant occurrence of $P$. martinii and Prinsius dimorphosus defines the $P$. martinii Zone, which is located between Samples 114-700B-32R-2, $83-85 \mathrm{~cm}$, and 114-700B-33R-CC. The abundant occurrence of $P$. dimorphosus between Samples 114-700B-34R-2, 105-106 $\mathrm{cm}$, and 114-700B-36R-CC indicates the presence of the $P$. dimorphosus Zone.

\section{Cretaceous}

A sample examined from the top of Core 114-700B-37R as part of the shipboard study contained an exclusively Cretaceous nannoflora; thus, the Cretaceous/Tertiary boundary is considered to lie within the break between Cores 114-700B$36 \mathrm{R}$ and 114-700B-37R. The occurrence of Nephrolithus frequens and the absence of Biscutum magnum between Samples 114-700B-37R-2, 31-32 cm, and 114-700B-38R-CC indicates the presence of the $N$. frequens Zone. The occurrence of $B$. magnum together with $N$. frequens in Sample 114-700B$39 \mathrm{R}-2,32-33 \mathrm{~cm}$, indicates the presence of the B. magnum Zone. The Reinhardtites levis Zone is present between Samples 114-700B-39R-CC and 114-700B-41R-2, 23-24 cm, as indicated by the co-occurrence of $R$. levis and $N$. frequens. The interval between the FAD of $N$. frequens and the LAD of Monomarginatus primus defines the Kamptnerius magnificus Zone between Samples 114-700-41R-CC and 114700B-43R-2, $32-33 \mathrm{~cm}$. The $M$. primus Zone is present between Samples 114-700B-43R-CC and 114-700B-45R-2, 61-62 cm; the Broinsonia parca Zone is present between Samples 114-700B-46R-2, 69-70 cm, and 114-700B-46R-CC; and the Eiffellithus eximius Zone is present between Samples 114-700B-47R-2, 93-94 cm, and 114-700B-49R-CC. The tops of all three of these zones are defined by the LADs of their nominate taxons. Only Sample 114-700B-50R-2, 26-27 $\mathrm{cm}$, contains Orastrum campanensis, and it is assigned to the $O$. campanensis Zone.

A stratigraphic break possibly representing most of the Campanian and possibly some of the Santonian separates Samples 114-700B-50R-2, 26-27 cm, and 114-700B-50R-CC. The presence of Seribiscutum primitivum between Samples 114-700B-50R-CC and 114-700B-51R-CC indicates the presence of the $S$. primitivum Zone. The co-occurrence of Lithastrinus floralis and Arkhangelskiella cymbiformis between Samples 114-700B-52R-CC and 114-700B-54R-CC indicates the presence of the $L$. floralis Zone.

\section{Site 701}

Site $701\left(51^{\circ} 59.07^{\prime} \mathrm{S}, 23^{\circ} 12.73^{\prime} \mathrm{W}\right.$; water depth $\left.4636.7 \mathrm{~m}\right)$ is on the western flank of the Mid-Atlantic Ridge about $160 \mathrm{~km}$ east of the Islas Orcadas Rise. The major objective of this site was to obtain a continuous sediment record of the development of an oceanic gateway for deep circulation between the South Atlantic and the Weddell Basin.

The sedimentary sequence penetrated at Site 701 was divided into three lithostratigraphic units. Unit $\mathrm{I}$ is predominantly a diatom ooze with varying additional clay, mud, and volcanic ash; Unit II is a diatom-bearing mud with less volcanic ash than above; and Unit III consists of indurated nannofossil chalk. Basalt, either from a sill or oceanic basement, was recovered from the last core barrel. Only Samples 114-701A-4H-4, 12-13 cm, and 114-701C-25X-3, 
34-95 cm, were recorded with in-situ nannofossils in Unit I. Strongly etched nannofossils occur sporadically throughout Unit Il, whereas in Unit III (below Sample 114-701C-49X-6, 29-30 cm), the nannofossils are overgrown with secondary valcite.

\section{Quaternary to Miocene}

Only Sample 114-701A-4H-4, 12-13 cm, from the Quaternary to Miocene strata in Hole 701A was found to contain nannofossils. The co-occurrence of Pseudoemiliania lacunosa and Gephyrocapsa spp. indicates a middle Pleistocene to Pliocene age. All other samples examined from Hole 701A were barren of nannofossils. Monospecific nannofossil floras of Reticulofenestra perplexa are present in Samples 114-701C$25 \mathrm{X}-3,94-95 \mathrm{~cm}$, to $114-701 \mathrm{C}-26 \mathrm{X}-\mathrm{CC}$. These indicate a late to middle Miocene age.

\section{Oligocene to Eocene}

The interval from Samples 114-701C-27X-CC to 114-701C$43 \mathrm{X}-2,34-35 \mathrm{~cm}$, contains only reworked nannofossils. Strongly etched in-situ nannofossil floras occur sporadically in the interval between Samples 114-701C-43X-4, 34-35 cm, and 114-701C-47X-2, 30-31 cm. These nannofossil floras include Isthmolithus recurvus, Reticulofenestra bisecta, Reticulofenestra umbilicus, Chiasmolithus altus, Clausicoccus subdistichus (only in Sample 114-701C-44X-2, 130-131 cm), Cyclicargolithus floridanus, Blackites spinosus, and Chiasmolithus sp. This interval is assigned to the undifferentiated $I$. recurvus Zone on the basis of the co-occurrence of 1 . recurvus and $C$. subdistichus.

Below this interval, $I$. recurvus is absent from the sparse nannofloras, and Chiasmolithus oamaruensis, the FAD of which defines the base of the $C$. oamaruensis Zone, is present in samples from the interval between Samples 114-701C47X-CC and 114-701C-48X-CC.

A stratigraphic break probably occurs between Samples 114-701C-48X-CC and 114-701C-49X-1, 27-28 cm, where there is also a change in the nannofossil floras from predominantly etched forms to strongly overgrown forms. The occurrence of Nannotetrina fulgens/Nannotetrina cristata in Samples 114-701C-49X-1, 27-28, and 114-701C-49X-3, $30-31 \mathrm{~cm}$, indicates the presence of the $N$. fulgens Zone. Sample 114-701C-50X-1, 75-76 cm, is assigned to the Discoaster sublodoensis Zone. It has a nannofossil flora similar to that recorded in the overlying interval, but without $N$. fulgens/N. cristata. Sample 114-701C-51X-CC is barren of calcareous nannofossils and is believed to be of igneous origin.

\section{Site 702}

Site $702\left(50^{\circ} 56.786^{\prime} \mathrm{S}, 26^{\circ} 22.117^{\prime} \mathrm{W}\right.$; water depth $\left.3084 \mathrm{~m}\right)$ is located on the central part of the Islas Orcadas Rise. The major objectives of this site were (1) to determine the age, nature, and subsidence history of the Islas Orcadas Rise and (2) to investigate the influence of the shallow Islas Orcadas and Meteor rises on oceanic water mass communication between the southern high-latitude region and the South Atlantic.

The sedimentary sequence penetrated at Site 702 was divided into two lithostratigraphic units. Unit I (down to Section $114-702 \mathrm{~B}-3 \mathrm{H}-4,80 \mathrm{~cm}$ ) consists of diatom mud to muddy diatom ooze overlying alternating nannofossil diatom ooze and diatom nannofossil ooze; Unit II is a sequence of nannofossil oozes, chalks, and indurated chalks with intercalated cherts, particularly in the lower part of the section. Samples above Sample 114-702B-6X-CC contain slightly etched nannofossil floras and those below that depth are overgrown with secondary calcite.

\section{Quaternary to Miocene}

The nannofossil floras of Sections $114-702 \mathrm{~B}-1 \mathrm{H}-\mathrm{CC}$ to 114-702B-2H-CC are dominated by Reticulofenestra perplexa, with lesser numbers of Coccolithus pelagicus. This assemblage indicates the presence of upper to middle Miocene strata.

\section{Eocene}

A stratigraphic break was recognized in both Holes 702A and 702B, with some Miocene, Oligocene, and upper Eocene strata absent. In Hole 702B, this break lies between Samples 114-702B-2H-CC and 114-702B-3H-CC. Samples 114-702B$3 \mathrm{H}-\mathrm{CC}$ to $114-702 \mathrm{~B}-5 \mathrm{X}-\mathrm{CC}$ are assigned to the Chiasmolithus oamaruensis Zone, on the basis of the presence of $C$. oamaruensis and Neococcolithes dubius and the absence of Isthmolithus recurvus. No samples that could be assigned to the Discoaster saipanensis Zone were examined. The absence of this zone is discussed within "Paleoenvironment and Provincialism."

The interval between Samples 114-702B-6X-2, 69-70 cm, and 114-702B-9X-CC is assigned to the Chiasmolithus solitus Zone. The interval between Samples 114-702B-10X-5, 20-21 $\mathrm{cm}$, and 114-702B-14X-CC is assigned to the Nannotetrina fulgens Zone. This assignment is based on the presence of $N$. fulgens/Nannotetrina cristata in the lowermost two samples. Supporting evidence comes from the presence of Sphenolithus furcatolithoides in Sample 114-702B-11X-CC and Chiasmolithus gigas in Samples 114-702B-12X-2, 20-21 cm, and 114702B-12X-CC.

Samples $114-702 \mathrm{~B}-15 \mathrm{X}-2,60-61 \mathrm{~cm}$, to $114-702 \mathrm{~B}-21 \mathrm{X}-\mathrm{CC}$ are assigned to the Discoaster sublodoensis Zone. This assignment is based on the FAD of $D$. sublodoensis in the lowest section. Sample 114-702B-22X-2, 20-21 cm, is assigned to the Discoaster lodoensis Zone. The occurrence of Tribrachiatus orthostylus between Samples 114-702B-22X-CC and 114-702B26X-CC indicates the presence of the $T$. orthostylus Zone.

\section{Paleocene}

The co-occurrence of Discoaster multiradiatus and the Fasciculithus tympaniformis group in Samples 114-702B$27 \mathrm{X}-1,6-7 \mathrm{~cm}$, to $114-702 \mathrm{~B}-27 \mathrm{X}-\mathrm{CC}$ indicates the presence of the $D$. multiradiatus Zone. The Eocene/Paleocene boundary lies near the top of this zone. The absence of $D$. multiradiatus and the presence of Heliolithus riedelii in Sample 114-702B$30 \mathrm{X}-\mathrm{CC}$ indicate the presence of the $H$. riedelii Zone for the interval between Samples 114-702B-28X-CC and 114-702B30X-CC.

Sample 114-702B-31X-CC contains Heliolithus kleinpellii and is thus assigned to the zone of that name. The continued presence of the $F$. tympaniformis group below the FAD of $H$. kleinpellii, in Sample 114-702B-32X-CC, indicates the presence of the $F$. tympaniformis group Zone. The abundance of $H$. kleinpellii is very low so its FAD in this hole may not be its true FAD.

\section{Site $\mathbf{7 0 3}$}

Site $703\left(47^{\circ} 03.042^{\prime} \mathrm{S}, 07^{\circ} 53.679^{\prime} \mathrm{E}\right.$; water depth $\left.1796 \mathrm{~m}\right)$ is located on the Meteor Rise. The major objectives of drilling at this site were to determine the nature, age, and subsidence history of the rise and to investigate the influence of the shallow Paleogene Meteor Rise, Islas Orcadas Rise, and the adjacent fracture zones on oceanic communication between the high and temperate latitudes of the South Atlantic. 
The sedimentary sequence consists of mainly nannofossil oozes with chalks in the lower part of the sequence (below Core 114-703A-26X). At the bottom of Hole 703A, basalt and tuff were found intermixed with sediments, although it was not possible to tell if this represented true basement. The Pleistocene to Pliocene nannofossil floras (above Sample 114703A-2H-CC) comprise slightly etched fossils. The Miocene to middle Eocene nannofossils below are overgrown with secondary calcite deposition, which increases downhole.

\section{Quaternary to Pliocene}

Samples 114-703A-1H-1, 1-2 cm, to 114-703A-2H-CC contain sparse nannofossil floras, including Pseudoemiliania lacunosa and Gephyrocapsa spp. The co-occurrence of these taxa indicates the presence of middle Pleistocene to upper Pliocene strata.

\section{Lower Miocene to Oligocene}

A stratigraphic break lies between Samples 114-703A$2 \mathrm{H}-\mathrm{CC}$ and $114-703 \mathrm{~A}-3 \mathrm{H}-2,134-135 \mathrm{~cm}$, with most of the Miocene and Pliocene absent. The nannofossil floras recovered from the interval between Samples 114-703A-3H-2, $134-135 \mathrm{~cm}$, and 114-703A-4H-CC are dominated by Cyclicargolithus floridanus; also present are rare Cyclicargolithus abisectus and Chiasmolithus altus. This may belong to the $C$. abisectus Zone or may represent reworking of $C$. abisectus and $C$. altus into younger Miocene strata. The presence of $C$. floridanus indicates a middle Miocene or older age.

The abundant occurrence of $C$. abisectus in Sample 114-703A-5H-2, 20-21 cm, indicates the presence of definite C. abisectus Zone strata. The interval between Samples 114-703A-5H-CC and 114-703A-7H-2, 10-11 cm, is assigned to the Reticulofenestra bisecta Zone, as the nominate taxon occurs in all samples from this interval. The first consistent downhole common occurrence of $C$. altus in Sample 114$703 \mathrm{~A}-7 \mathrm{H}-5,10-11 \mathrm{~cm}$, indicates the presence of the $C$. altus Zone, which extends down to Sample 114-703A-11H-CC. The LAD of Reticulofenestra umbilicus defines the top of the underlying Reticulofenestra daviesii Zone, which lies between Samples 114-703A-12H-2, 22-23 cm, and 114$703 \mathrm{~A}-12 \mathrm{H}-4,24-25 \mathrm{~cm}$. The abundant occurrence of Clausicoccus subdistichus in the interval between Samples 114$703 \mathrm{~A}-12 \mathrm{H}-6,21-22 \mathrm{~cm}$, and $114-703 \mathrm{~A}-12 \mathrm{H}-\mathrm{CC}$ indicates the presence of the C. subdistichus Subzone of the Isthmolithus recurvus Zone.

\section{Eocene}

The Reticulofenestra oamaruensis Subzone is recognized below the LAD of the nominate taxon at Sample 114-703A$13 \mathrm{H}-2,74-75 \mathrm{~cm}$, down to Sample 114-703A-15H-2, 95-96 $\mathrm{cm}$; the Oligocene/Eocene boundary probably lies within this subzone. Sample 114-703A-15H-CC, in which Discoaster saipanensis and Isthmolithus recurvus co-occur, is assigned to the $I$. recurvus Subzone. The interval between the FAD of $I$. recurvus and the FAD of Chiasmolithus oamaruensis defines the $C$. oamaruensis Zone between Samples 114-703A-16X-1, 20-21 cm, and 114-703A-20X-2, 30-31 cm.

A possible hiatus separates the $C$. oamaruensis and Chiasmolithus solitus Zones, with the D. saipanensis Zone absent. This is discussed within "Paleoenvironment and Provincialism." The co-occurrence of Reticulofenestra bisecta and $C$. solitus indicates the presence of the $C$. solitus Zone between Samples 114-703A-20X-CC and 114-703A22X-CC. The interval between Samples 114-703A-23X-1, $20-21 \mathrm{~cm}$, and $114-703 \mathrm{~A}-30 \mathrm{X}-\mathrm{CC}$ is assigned to the Nan- notetrina fulgens Zone, and the FAD of $N$. fulgens/N. cristata lies in the lowest sample in the interval. Supporting evidence for this zonal assignment is provided by the occurrence of Sphenolithus furcatolithoides in Sample 114$703 \mathrm{~A}-30 \mathrm{X}-2,30-32 \mathrm{~cm}$. The only sample available for study in the lower part of the hole is Sample 114-703A-33X-CC. This sample contains Reticulofenestra umbilicus, the FAD of which lies within the Discoaster sublodoensis to Discoaster lodoensis Zones.

\section{Site 704}

Site $704\left(46^{\circ} 52.757^{\prime} \mathrm{S}, 07^{\circ} 25.250^{\prime} \mathrm{E}\right.$; water depth $\left.2532.3 \mathrm{~m}\right)$ is located on the southern part of the Meteor Rise. Site 704 was located where a maximum thickness of Neogene and upper Paleogene sediment could be obtained in order to provide a high-resolution paleoceanographic-paleoclimatic record of an interval not well represented at the preceding Leg 114 sites.

The sedimentary sequence was divided into two lithostratigraphic units. Unit I consists of varying admixtures of two end-member components, namely calcareous oozes and chalks consisting of foraminifers and calcareous nannofossils and siliceous oozes composed of diatoms with minor radiolarians and silicoflagellates. Unit II consists of micritic-bearing nannofossil chalk passing down into micritic indurated nannofossil chalk. The nannofossils from the upper part of Hole 704B (above Core 114-704B-10H) consist of slightly etched coccoliths. Below this depth, they become increasingly overgrown with secondary calcite.

\section{Hole $704 \mathrm{~A}$}

\section{Quaternary}

The upper part of Hole 704A is the subject of a separate study (Gard and Crux, this volume). This study has shown that the upper part of this hole is much younger than was reported by Ciesielski, Kristoffersen, et al. (1988). Dominant Emiliania huxleyi in Sample 114-704A-1H-2, $24 \mathrm{~cm}$, and above indicates the presence of sediments from oxygen isotope stage $5 \mathrm{a}$ or younger (Thierstein et al., 1977). The continued presence of $E$. huxleyi down to at least Sample 114-704A-1H-3, 104 $\mathrm{cm}$, indicates an age no older than mid-oxygen isotope stage 8 (0.268 Ma; Thierstein et al., 1977). The LAD of Pseudoemiliania lacunosa has been recognized in Sample 114-704A$1 \mathrm{H}-5,105 \mathrm{~cm}$, and the interval from this sample down to Sample 114-704A-13X-CC is assigned to Zone NN19. Samples from the interval between Samples 114-704A-14H-5, 33-34 $\mathrm{cm}$, and 114-704A-15H-CC additionally contain Helicosphaera sellii, a species with a LAD within NN19; thus these samples can be assigned to the lower part of NN19 (lower Pleistocene).

The very rare occurrence of Discoaster brouweri and the presence of Calcidiscus macintyrei in Sample 114-704A$16 \mathrm{H}-\mathrm{CC}$ indicate the presence of Zone NN18 or older strata. The very rare occurrence of Discoaster pentaradiatus in Sample 114-704A-18X-CC indicates the presence of Zone NN17 or older strata, whereas the presence of very rare Discoaster surculus in Sample 114-704A-20X-CC indicates the presence of NN16 or older strata. These fossils are all very rare, and their last occurrences, which are used to zone the upper Pliocene, are not necessarily their extinctions. The continued occurrence of Gephyrocapsa spp. down to Sample 114-704A-22X-CC indicates the presence of NN15 or younger strata. Rare specimens of Reticulofenestra pseudoumbilicus possibly restrict this sample to $\mathrm{NN} 15$, but these may be reworked. 
A stratigraphic break may occur between Samples 114704A-22X-CC and 114-704A-23X-CC. This is reflected in the nannofossil flora by an abrupt change in the assemblages from those dominated by Coccolithus pelagicus to those dominated $R$. pseudoumbilicus. This change could alternatively be interpreted as a paleoceanographic change (Müller et al., this volume).

Samples 114-704A-23X-CC and 114-704A-24X-CC are assigned to Zones NN15-11 on the basis of the presence of $R$. pseudoumbilicus in both samples and Amaurolithus delicatus in the lower sample. Below Sample 114-704A-25X-CC, the strata are assigned to Zones NN15-?7. The nannofossil floras are of low diversity and are dominated by $R$. pseudoumbilicus, Reticulofenestra perplexa, and $C$. pelagicus.

\section{Hole $704 B$}

The higher part of this hole has not been reexamined; the preliminary results are presented in Ciesielski, Kristoffersen, et al. (1988). However, the revisions to the younger part of Hole $704 \mathrm{~A}$ probably apply to this hole as well.

The interval between Samples 114-704B-14H-CC and 114704B-16X-CC contains $H$. sellii, a species with an LAD within Zone NN19.

The very rare occurrence of $D$. brouweri and the presence of $C$. macintyrei in Sample 114-704B-17X-CC indicate the presence of NN18 or older strata. No older Pliocene zones were recognized in the interval between Samples 114-704B17X-CC and 114-704B-21X-CC, although comparisons to Hole $704 \mathrm{~A}$ would suggest that they are probably present.

A stratigraphic break or paleoceanographic change may occur between Samples 114-704B-21X-CC and 114-704B-22XCC. This is reflected in the nannofossil floras by an abrupt change from assemblages dominated by $C$. pelagicus to those dominated by $R$. pseudoumbilicus.

Samples 114-704B-22X-CC to 114-704B-24X-CC are assigned to Zones NN14-9 (lower Pliocene-middle Miocene) on the basis of the presence of Amaurolithus tricorniculatus (NN14-11) in the highest sample and Discoaster pentaradiatus in the lowest sample. The underlying interval between Samples 114-704B-25X-CC and 114-704B-45X-CC is assigned to Zones NN14-?7. Samples within this interval contain abundant nannofossil floras of low diversity that lack age-diagnostic species. The dominance of these floras by $C$. pelagicus, $R$. perplexa, and $R$. pseudoumbilicus together with their stratigraphic position confirms this age assignment.

An abrupt change in the nannofossil flora between Samples 114-704B-45X-CC and 114-704B-46X-CC indicates a stratigraphic break. The co-occurrence of Sphenolithus heteromorphus and $C$. macintyrei in the latter sample indicates the presence of Zones NN5-4. The nannofossil floras from this interval are dominated by Cyclicargolithus floridanus and $C$. pelagicus.

Samples below the FAD of $C$. macintyrei are assigned to between NN4 and the Cyclicargolithus abisectus Zone, between Samples 114-704B-50X-CC and 114-704B-63X-CC. No zonal index taxa are present, with the exception of $C$. abisectus. This species appears to range as high as Zone NN5 in this area, or it is reworked. Whichever the case, the top of the $C$. abisectus Zone cannot be accurately picked in Hole 704B. The $R$. bisecta Zone is recognized in Sample 114-704B-64X-CC by the occurrence of the nominate taxon. The top of the Chiasmolithus altus Zone is recognized in Sample 114-704B-65X$\mathrm{CC}$ by the consistent and significant occurrence of the nominate taxon. This zone is present down to the lowest Sample 114-704B-72X-CC.

\section{PALEOENVIRONMENT AND PROVINCIALISM Cretaceous}

The nannofossil floras recovered from the Upper Cretaceous sections penetrated by Holes $698 \mathrm{~A}$ and $700 \mathrm{~B}$ are poor to very poorly preserved. This should be taken into account in drawing any conclusions as to their paleoenvironmental and biogeographic significance. Another prerequisite for studies of the paleoenvironmental significance of these nannofossil floras is a reliable means of correlation between these sites and other areas both near and far. Previous studies (Ciesielski et al., 1977; Wind, 1979) on the paleoenvironmental significance of high-latitude nannofossil floras from the South Atlantic and Indian oceans have been hampered by the lack of a good zonal scheme for this area. These studies made comparisons of the nannofossil floras recovered in high-latitude areas using correlations derived from foraminiferal studies. They were also based on relatively incomplete sections.

Until Hole 700B was drilled, no sedimentary succession without major breaks had been recovered from the Maestrichtian of the high-latitude South Atlantic. Wind and Wise (1983) attempted to summarize the stratigraphic positions of the cores recovered by Deep Sea Drilling Project (DSDP) Legs 36 and 71 and the Islas Orcadas Core $1 \varnothing$ 07-75-44. This summary would appear to need modification in the light of the present findings.

In the present study, the following approach has been used to establish a nannofossil zonal framework with which to make direct comparisons of nannofossil floras of the same age from other areas. It is first assumed that cosmopolitan nannofossil datums, such as the LADs of Eiffellithus eximius, Broinsonia parca, and Reinhardtites levis, are approximately synchronous in different latitudes. Second, nannofossil datums observed in high-latitude areas of the Northern Hemisphere, such as the LADs of Orastrum campanensis and Biscutum magnum and the FAD of Nephrolithus frequens, are considered to lie at approximately the same level in the Southern Hemisphere. The dating of cores and the positioning of the Maestrichtian/Campanian boundary relative to the nannofossil datums are critical for some of the previous paleoenvironmental interpretations. Ciesielski et al. (1977) compared cores recovered by DSDP Leg 36 at Site 327 with a series of cores from the Maurice Ewing Bank, in particular Islas Orcadas Core $1 \varnothing$ 07-75-44. They concluded that differences between the nannofloras of the two areas were accounted for by a major water-mass boundary lying between them. The findings of the present study would, however, suggest that the material recovered from DSDP Site 327 was younger than that recovered from the Islas Orcadas core. Thus, no paleoenvironmental explanations are necessary to account for the observed differences. The presence of Eiffellithus eximius and the absence of Monomarginatus spp. (not including Monomarginatus primus) and Biscutum magnum suggest an earliest Maestrichtian or older age for the Islas Orcadas core. The presence of Monomarginatus spp. and $B$. magnum and the absence of $E$. eximius suggest an early to late Maestrichtian age for the sediments recovered from DSDP Site 327.

Differences in taxonomic concepts of different authors prevent detailed comparisons of the nannofossils from material recovered by previous DSDP and Islas Orcadas cruises and those of the present study. In addition, the nannofossil floras recovered from Holes $698 \mathrm{~A}$ and $700 \mathrm{~B}$ are poorly preserved, as noted previously. The following observations can be made despite these limitations. 
The nannofossil floras of the Santonian sediments recovered from Hole 700B are very similar to those of the same age in the Northern Hemisphere. The most notable difference is the presence of Seribiscutum primitivum in the Southern Hemisphere, whereas this species is not found above the Cenomanian in the Northern Hemisphere (Forchheimer, 1968; Crux, 1982). The LAD of Lithastrinus floralis, in contrast, may be later in the high latitudes of the Northern Hemisphere; Crux (1982) and Bukry (1969) recorded this species from the Campanian.

Only Sample 114-700B-50R-2, 26-27 cm, was recovered from strata that could be confidently assigned to the Campanian. The nannofossil flora of this sample was so poorly preserved that no useful comparisons can be made with other areas.

The nannofossil floras from the Maestrichtian sediments recovered from Holes 698A and 700B are very similar to those recorded by Wise and Wind (1977) and Wind and Wise (1983) (DSDP Legs 36 and 71), although less well preserved. Distinctive high-latitude species common to these studies and the present study include Biscutum coronum, Nephrolithus corystus, Biscutum dissimilis, Teichorhabdus ethmos, N. frequens, B. magnum, and Monomarginatus pectinatus/M. quaternarius. Species present only in the Falkland Plateau region include Boletuvelum candens, Centosphaera barbata, $\mathrm{Lu}$ cianorhabdus arborius, Okkolithus australis, Orastrum asarotrum, Ottavianus giannus, "Phanulithus" additus, and Pharus simulacrum. Most of the differences in the assemblages recorded in the Falkland Plateau region and this study can be accounted for by variations in preservation and the different taxonomic concepts of the authors. It is remarkable, though, that many of the species absent from the assemblages from the Northeast Georgia Rise but present in the Falkland Plateau region are holococcoliths. This group of coccoliths is usually best preserved in shallow-water areas (Perch-Nielsen, 1985). The absence of many of the holococcoliths from the Northeast Georgia Rise area in the Maestrichtian could possibly be attributed to a deeper water environment than that of the Falkland Plateau region.

Holococcoliths are structurally weaker than heterococcoliths. This structural weakness commonly leads to their destruction before they are included in the sediment. In the sediments studied from the Northeast Georgia Rise, the poor preservation of the nannofossils is probably controlled by diagenetic processes, rather than destruction before burial, with progressive lithification downhole. Under such conditions, holococcoliths can, in fact, be preferentially preserved, as in the chalks of southern England, where members of the genera Lucianorhabdus and Calculites are common (Crux, 1980).

Thus, it is possible the absence of some of the holococcoliths from the Northeast Georgia Rise area is due to their preference for shallow-water environments. The species of holococcoliths recorded in the Northeast Georgia Rise area are not as common as they are in the Falkland Plateau region.

The most remarkable feature of the Maestrichtian nannofossil floras from the Northeast Georgia Rise area is their similarity to floras of the same age from high-latitude areas in the Northern Hemisphere, in particular the North Sea region. The succession of biostratigraphic events recorded in the North Sea region is almost identical to that recorded on the Northeast Georgia Rise. The occurrence of a species such as $B$. magnum in both areas and its LAD between those of $R$. levis and $N$. frequens are remarkable because this species has not been recorded in areas between these two regions. Important differences do occur, however, between the floras of the two regions, in particular the LAD of $M$. primus, which is recorded at approximately the same level as the LAD of $O$. campanensis in the North Sea but ranges above the LADs of E. eximius and B. parca in the Northeast Georgia Rise area. In addition to the differences in the stratigraphic ranges of some of the species, many of the species recorded in the Falkland Plateau region and the Northeast Georgia Rise have never been recorded in the Northern Hemisphere.

\section{Paleocene}

Paleocene nannofloras recovered during Leg 114 were from Sites 698-702 in the western part of the study area (Fig. 1). The most complete section recovered was from Hole $700 \mathrm{~B}$ (Table 3). The other less complete successions appear to be very similar to this section. The preservation of the nannofossil floras is very poor throughout the Paleocene of Hole $700 \mathrm{~B}$, with considerable overgrowth of secondary calcite on the nannofossils.

The nannofossil floras are dominated by Prinsius and Toweius in succession. Assemblages dominated by Prinsius martinii and Prinsius bisulcus were considered characteristic of highlatitudes by Haq and Lohmann (1976). They also noted a relatively high abundance of Chiasmolithus spp. in such latitudes. This is confirmed in the present study, where Chiasmolithus makes up between $3 \%$ and $15 \%$ of the nannofossil flora through most of the latter part of the Paleocene. The rarity of Heliolithus and Discoaster in the upper Paleocene is also attributed to the high-latitude location of these sites.

These Paleocene nannofossil floras are similar to those of the high-latitude Northern Hemisphere areas. Differences between the assemblages from the North Sea area for the Prinsius dimorphosus to Fasciculithus tympaniformis group Zones include the comparative lack of Neochiastozygus spp. and the absence of Octolithus multiplus in the South Atlantic sites.

\section{Eocene}

The nannofossil floras recovered during Leg 114 for the lower Eocene were all from Sites 698-702, which lie in the western part of the study area (Fig. 1). Those from the middle to upper Eocene also include recovery from Site 703, which lies farther east. The most complete and best preserved section through the Eocene is from Site 699 (Tables 1 and 2). The preservation of the nannofossil floras throughout the Eocene sections is poor to very poor.

The nannofossil floras from the Eocene sections are dominated by Toweius pertusus, Toweius crassus, Reticulofenestra dictyoda, Reticulofenestra hillae, and Cribrocentrum coenurum in succession through the lower to lower upper Eocene. Above this level, the dominance of the nannofossil floras alternates rapidly among the Cyclicargolithus floridanus group, Reticulofenestra daviesii group, Reticulofenestra umbilicus, and Coccolithus pelagicus. This pattern continues into the Oligocene. The patterns of dominance of the nannofossil floras can be used for an approximate biostratigraphy of the Eocene. There is, however, some evidence to suggest that these shifts of dominance may not be isochronous throughout the study area.

The abrupt LAD of $C$. coenurum and the closely related species $C$. reticulatum, which dominates the assemblages of the lowest upper Eocene in Hole 699A, is below the FAD of Isthmolithus recurvus. In Hole $703 \mathrm{~A}$, the abundant occurrence of $C$. coenurum continues to occur above the level of the FAD of $I$. recurvus. This latter sequence of events is the same as reported by Perch-Nielsen (1985) in low-latitude areas, whereas the former is typical of high latitudes.

Alternative explanations for the sequence of events changing from west to east are a diachronous FAD for I. recurvus, a diachronous LAD for $C$. coenurum, or that both events are 
diachronous. I. recurvus is known to prefer high latitudes (Perch-Nielsen, 1985), whereas $C$. reticulatum (and presumably the closely related $C$. coenurum) was identified by $\mathrm{Haq}$ and Lohmann (1976) as typical of midlatitude assemblages. Thus we have two species with different environmental preferences. The FAD of $I$. recurvus is the harder event to define accurately, because of the very low numbers of specimens in the early part of its range. It is tempting to assume that this species occurred or appears to occur later at Hole 699A, because of the low number of specimens involved.

Depending on which event one considers to be isochronous, if either, the differences in the sequences of the events in the two areas may provide evidence for water circulation patterns for the late Eocene. It possibly suggests warmer surface waters on the eastern side of the South Atlantic to those of the western side, resulting in an earlier decline of $C$. coenurum in the west.

Another biostratigraphic problem caused by the environmental preferences of index taxa is the existence or absence of the Discoaster saipanensis Zone in the study area. This zone is defined as the interval between the LAD of Chiasmolithus solitus and Chiasmolithus oamaruensis. Both of these species belong to the genus Chiasmolithus, which has a preference for high-latitude/cold-water areas. In the present study the two events were found to occur very close to one another, but the two do not co-occur. It is assumed that this pattern is the result of the species both reaching their maximum stratigraphic ranges in this area. An alternative explanation would be the existence of a regional hiatus at this level causing the $D$. saipanensis Zone sediments to be absent. The $D$. saipanensis Zone is reported by Perch-Nielsen (1985) to have some very thick sections in low latitudes, where the stratigraphic ranges of the index taxa are shortened, thus expanding this zone. Wei and Wise (1989) have recently reported that $C$. solitus has a longer stratigraphic range in high latitudes, which explains at least some of the distribution pattern seen. The use of the $\mathrm{LAD}$ of $C$. solitus and FAD of $C$. oamaruensis within the study area as biostratigraphic datums is still considered valid, as there is little latitudinal variation. Comparisons with other areas should be made very carefully, as the $D$. saipanensis Zone increases in thickness in lower latitudes. It has not been possible to prove the total absence of the $D$. saipanensis Zone in the study area, although if present, it must be less than $2 \mathrm{~m}$ thick in Hole 699A.

The nannofossil floras recovered from the Eocene sections of the sites in the present study are, as previously noted, dominated by successive groups of placoliths, with the persistent occurrence of Chiasmolithus throughout. These are typical of high-latitude assemblages. Groups that are absent or rare in the material recovered include the warmer water/lowlatitude Discoaster, Helicosphaera, and Sphenolithus. It is probable that the levels where these groups do occur were deposited during relatively warmer intervals, when low-latitude warmer waters were able to move farther south into the study area.

Discoasters are most common within the lower to lower middle Eocene (Tribrachiatus orthostylus to Discoaster sublodoensis Zone). They occur less commonly in the middle middle Eocene (Nannotetrina fulgens to $C$. solitus Zones), but become more common in the upper middle Eocene to upper Eocene ( $C$. solitus to $I$. recurvus Zones). Helicosphaera is almost totally absent from the study area. It is present in a short interval in the lower Eocene ( $T$. orthostylus to $D$. lodoensis Zones) and in a single sample in the middle Eocene (C. solitus Zone). Sphenolithus occurs rarely throughout the Eocene, but is more common in the lower to middle Eocene (T. orthostylus to D. sublodoensis Zones).
These patterns suggest that the early to early middle Eocene was a period with comparatively warm surface water. A cooler period occurred in the middle middle Eocene, and warmer conditions returned in the late middle to late Eocene. These findings are similar to the conclusions of the much more detailed study of Haq and Lohmann (1976), who recorded maximum poleward migrations of low-latitude nannofloras in the early middle Eocene (D. sublodoensis Zone) and the late Eocene (I. recurvus Zone, this study).

In addition to the temperature-sensitive groups described previously, the distribution of Zygrhablithus bijugatus is of interest. This species is a robust holococcolith with a total stratigraphic range from the upper Paleocene to the lowest Miocene. In the present study, it is found to occur in the upper Paleocene to lower Eocene and the upper middle Eocene. This might indicate that its distribution is also temperature controlled, as the intervals it occurs in are those influenced by warm surface water. The high abundance of this species in the upper Paleocene to lower Eocene may also be related to water depth, as this species is more commonly preserved in water depths of less than $1000 \mathrm{~m}$ (Edwards, 1973).

\section{Oligocene-Lowest Miocene}

Oligocene to lowest Miocene nannofossil floras were recovered from Sites 699, 701, 703, and 704. The most complete and thickest of these sections is from Hole 699A (Table 1). The preservation of the nannofloras in all the Oligocene sections is poor, with most of the assemblages etched by varying degrees. The Oligocene to lowest Miocene nannofossil floras are characterized by a lower diversity than those of the Eocene, with never more than 16 species present in one sample. The dominance of the assemblages alternates among the Cyclicargolithus floridanus group, the Reticulofenestra daviesii group, and Coccolithus pelagicus. Chiasmolithus rims and Chiasmolithus altus have some common to abundant occurrences and are always a significant element of the assemblage.

The low diversity and near total absence of the genera Discoaster, Helicosphaera, and Sphenolithus suggest that very cold-water conditions prevailed during most of the Oligocene to earliest Miocene. The presence in both Holes 699A and 703A of rare Discoaster deflandrei, Discoaster spp., and Discoaster adamanteus in the upper Oligocene to lowest Miocene (Reticulofenestra bisecta to Cyclicargolithus abisectus Zones) may indicate a period of warmer surface waters. Haq and Lohmann (1976) recorded a maximum poleward migration of warm-water/low-latitude nannofossils in the upper Oligocene, corresponding to the base of the $R$. bisecta Zone.

\section{Miocene to Quaternary}

Miocene to Quaternary cores recovered during Leg 114, except for those from Site 704, contain only short intervals of nannofossil-bearing sediments. These contain nannofossil floras of only two or three species. Such low diversities probably indicate cold surface waters at the time of deposition and/or etching of the nannofossils.

\section{Site 704}

The lower Miocene section of Hole 704B contains abundant nannofloras of very low diversity (fewer than eight species/sample). These are dominated by $C$. floridanus and $C$. pelagicus. The low diversity is probably indicative of cold surface waters during deposition; however, warm-water elements do occur throughout the interval. These are Sphenolithus heteromorphus, Sphenolithus moriformis, and Discoaster spp. 
A hiatus separates the lower Miocene from the middle to upper Miocene, where the nannofossil floras are again of very low diversity (fewer than eight species/sample). These are dominated by the cold-water species $C$. pelagicus and Reticulofenestra perplexa, with lesser numbers of Reticulofenestra pseudoumbilicus. Sphenolithus abies is rarely present in the lower part of this interval between Cores 114-704B-45X and 114-704B-34X. Helicosphaera carteri is present in Sample 114-704B-32X-CC. Discoasters are totally absent. It would thus appear that the middle to upper Miocene interval was deposited during a period of cold surface waters that were coldest at the end of the Miocene.

The Pliocene interval between Core 114-704B-27X and Sample 114-704A-17X-CC also contains low-diversity nannofossil floras (fewer than eight species/sample). Discoasters are present but rare throughout the Pliocene, with rare Amaurolithus in the lower Pliocene and Helicosphaera in the upper Pliocene. The nannofossil floras of the lower Pliocene are dominated by $R$. pseudoumbilicus, and those in the upper Pliocene by $C$. pelagicus. The Pliocene would appear, from the sparse occurrence of the discoasters and other warm water genera, to be slightly warmer than the latest Miocene.

The Pleistocene interval above Sample 114-704A-17X-CC contains abundant low-diversity nannofossil floras (fewer than eight species/sample). These are dominated by $C$. pelagicus with common Gephyrocapsa spp., which increase uphole. Calcidiscus leptoporus and Emiliania huxleyi are abundant in certain intervals in the top two cores. The paleoenvironmental significance of the nannofossils of this interval is the subject of a separate study (Gard and Crux, this volume).

\section{TAXONOMY}

Species discussed here are also listed in the Appendix. A number of species groupings were employed in the present study. These were used either because poor preservation did not allow the separation of the taxa concerned, or because the established taxonomic subdivisions of the groups are confused and based on dubious criteria. These groups are as follows.

\section{Mesozoic}

Arkhangelskiella cymbiformis-My concept of A. cymbiformis includes forms often assigned to Arkhangelskiella specillata. I believe these two species to be preservational conspecific morphotypes of one another.

Reinhardtites aff. $R$. anthophorus and $R$. levis-These two species are usually differentiated by the size of the two central openings either side of the central bridge. This division is difficult to apply in poorly preserved material where secondary calcite overgrowth can obscure the openings.

Monomarginatus pectinatus and Monomarginatus quaternarius-These two species are differentiated by the number of perforations bordering the outer rim. Secondary calcite overgrowth prevented the observation of these perforations.

\section{Cenozoic}

Fasciculithus tympaniformis group-Considerable overgrowth of secondary calcite on the members of the genus Fasciculithus prevented any reliable subdivision. The $F$. tympaniformis group thus includes all species of Fasciculithus present.

Chiasmolithus bidens and $C$. solitus-Even in well-preserved material, I have difficulty differentiating these two species with only the light microscope. In the Paleocene sections I have grouped them together.

Toweius pertusus and T. eminens-These two species are grouped together in the nannofossil distribution chart for the
Paleocene of Site 700 (Table 3) because the very poor preservation prevents their reliable and consistent separation.

Nannotetrina cristata and N. fulgens-The poor preservation of the sections studied does not allow the separation of these two species.

Reticulofenestra daviesii group_-This group includes all medium-sized Reticulofenestra with varying constructions of the central grid.

Cyclicargolithus floridanus group-This group includes all round to subelliptical imperforate small- to medium-sized placoliths recorded in the Eocene to lower Miocene. One new species is proposed from the present study.

\section{Genus MONOMARGINATUS Wind and Wise, 1977 \\ Monomarginatus primus $\mathrm{n}$. sp.}

Staurolithites ellipticus (Gartner), Crux, 1982, p. 116, pl. 5.3, figs. 13-15; pl. 5.9, fig. 20.

Description. An elliptical coccolith with a loxolith rim and two cross bars parallel with the major and minor axes of the ellipse. These bars are composed of numerous crystal elements and can support a very robust spine composed of numerous elements. Each of the four quadrants formed by the cross is nearly filled by a diagonal bar that links the bars of the cross.

Remarks. This species differs from $M$. quaternarius by the more robust nature of the central structure, which in overgrown specimens appears to completely fill the central area. The thick multielement spine of this species is very distinctive and is often seen detached under the light microscope. This species is possibly ancestral to the other species of Monomarginatus. Monomarginatus primus differs from Staurolithites ellipticus by its much larger size and distinctive spine.

Occurrence. Maestrichtian of Holes 698A and 700B; upper Campanian of Norfolk, UK.

Size. Holotype $9.4 \mu \mathrm{m}$ long, $5.9 \mu \mathrm{m}$ wide. Size range of observed specimens between 9 and $12 \mu \mathrm{m}$ long.

Holotype. From Crux (1982), pl. 5.3, fig. 20; negative number UCL-1028-22.

Paratypes. From Crux (1982), pl. 5.3, figs. 14 and 15; negative numbers UCL-1028-19 and UCL-1035-5.

Type locality. North Norfolk coast near West Runton, U.K.

\section{CONCLUSIONS}

Nannofossils are useful in dating and correlating the Cretaceous to Quaternary sediments deposited above the CCD in the high latitudes of the South Atlantic. The Cretaceous to the lowermost Miocene interval can be divided into 29 nannofossil zones and three subzones. This degree of biostratigraphic resolution is only slightly less than that achieved in lowlatitude areas under more optimal conditions.

The LADs of Eiffellithus eximius, Broinsonia parca, Reinhardtites levis, and Biscutum magnum occur in the same order in both the Northern and Southern hemispheres and are considered to be reliable as biostratigraphic datums in highlatitude areas.

The diachroneity of the FAD of Nephrolithus frequens, first reported by Wind (1979), is confirmed. This datum occurs in older sediments than the LAD of Reinhardtites levis in high-latitude areas of both the Northern and Southern hemispheres, while in low-latitude areas this order is reversed (Sissingh, 1977).

Monomarginatus primus n. sp. appears to have a later LAD in the Southern Hemisphere than in the Northern Hemisphere. In the Southern Hemisphere this datum occurs above the LADs of Broinsonia parca and Eiffellithus eximius, while in the Northern Hemisphere it is found below them.

Some of the Tertiary biostratigraphic datums used show more restricted or expanded stratigraphic ranges in the highlatitude South Atlantic area. In particular, the ranges of Chiasmolithus solitus and Chiasmolithus oamaruensis appear 
to be longer in the high latitudes. The ranges of Nannotetrina fulgens/N. cristata and Reticulofenestra bisecta appear to be shorter, when calibrated by magnetostratigraphy and compared to the findings of Wei and Wise (1989).

Differences in the relative positions of the LAD of Cribrocentrum coenurum and the FAD of Isthmolithus recurvus are observed between Holes 699A and 703A. This possibly suggests that warmer surface waters existed in the middle to late Eocene at Site 703 than at Site 699, as the warm-water species Cribrocentrum coenurum and $C$. reticulatum appear to have later LADs there.

The presence or absence of temperature-sensitive calcareous nannofossil floras reflects the changing surface-water temperatures of the area throughout the Cenozoic. The highest diversities are recorded in the Paleocene to Eocene sections, with warm-water genera present in the upper Paleocene to lower middle Eocene and in the upper middle to upper Eocene sediments. A marked drop in diversity occurs in the lower Oligocene, with warm-water genera occurring in the uppermost Oligocene to lowermost Miocene. Very low diversities are characteristic of the Miocene, and although some sphenoliths and discoasters occur in the lower Miocene, these are absent in the upper Miocene. The Pliocene contains some discoasters and Amaurolithus and Helicosphaera, which possibly indicates warmer surface waters in comparison to the late Miocene. Changes over short stratigraphic intervals in the nannofossil floras of the Pleistocene reflect a rapidly changing environment.

\section{ACKNOWLEDGMENTS}

I thank British Petroleum plc. for financial support during this study and permission to publish the results.

\section{REFERENCES}

Bukry, D., 1969. Upper Cretaceous coccoliths from Texas and Europe. Univ. Kansas Paleontol. Contrib., 51:1-79.

1973. Coccolith stratigraphy, eastern equatorial Pacific, Leg 16, Deep Sea Drilling Project. In van Andel, T. H., Heath, G. R., et al., Init. Repts. DSDP, 16: Washington (U.S. Govt. Printing Office), 653-711.

1975. Coccolith and silicoflagellate stratigraphy, northwestern Pacific Ocean, Deep Sea Drilling Project Leg 32. In Larson, R. L., Moberly, R., et al., Init. Repts. DSDP, 32: Washington (U.S. Govt. Printing Office), 677-701.

Bukry, D., and Bramlette, M. N., 1970. Coccolith age determinations Leg 3, Deep Sea Drilling Project. In Maxwell, A. E., Von Herzen, R. P., et al., Init. Repts. DSDP, 3: Washington (U.S. Govt. Printing Office), 589-611.

Cepek, P., 1970. Zur Vertikalverbreitung von Coccolithen-Arten in der Oberkreide NW-Deutschlands. Geol. Jahrb., 88:235-264.

Čepek, P., and Hay; W. W., 1969. Calcareous nannoplankton and biostratigraphic subdividions of the Upper Cretaceous. Trans. Gulf Coast Assoc. Geol. Soc., 19:323-336.

Ciesielski, P. F., Kristoffersen, Y., et al., 1988. Proc. ODP, Init. Repts., 114. College Station, TX (Ocean Drilling Program).

Ciesielski, P. F., Sliter, W. V., Wind, F. H., and Wise, S. W., Jr., 1977. Paleoenvironmental analysis of a Cretaceous Islas Orcadas core from the Falkland Plateau, southwest Atlantic. Mar. Micropaleontol., 2:27-34.

Crux, J. A., 1980. A biostratigraphical study of Upper Cretaceous calcareous nannofossils from south-east England and north France [Ph.D. thesis]. Univ. London.

1982. Upper Cretaceous (Cenomanian to Campanian) calcareous nannofossils. In Lord, A. R. (Ed.), A Stratigraphical Index of Calcareous Nannofossils: Chichester (Ellis Horwood), $81-135$.

Edwards, A. R., 1971. A calcareous nannoplankton zonation of the New Zealand Paleogene. In Farinacci, A. (Ed.), Proc. 2nd Planktonic Conf. Roma, 1971, 2:381-419.

1973. Calcareous nannofossils from the southwest Pacific. In Burns, R. E., Andrews, J. E., et al., Init. Repts. DSDP, 21: Washington (U.S. Govt. Printing Office), 641-691.
Forchheimer, S., 1968. Die Coccolithen des Gault-Cenoman, Cenoman and Turon in der Bohrung Höllviken I, Südwest-Schweden. Sver. Geol. Unders., Ser. C., 635, 62:1-84.

Haq, B. U., and Lohmann, G. P., 1976. Early Cenozoic calcareous nannoplankton biogeography of the Atlantic Ocean. Mar. Micropaleontol., 1:119-194.

Heck, S. E. van, 1979a. Bibliography and taxa. INA Newsl., 1:AB1B27.

INA Newsl., 1:N5-N6.

1979c. Bibliography and taxa. INA Newsl., 1:ABV1-B42.

1980a. Bibliography and taxa. INA Newsl., 2:5-34.

1980b. Bibliography and taxa. INA Newsl., 2:43-81.

1981a. Bibliography and taxa. INA Newsl., 3:4-41.

1981b. Bibliography and taxa. INA Newsl., 3:51-86.

1982a. Bibliography and taxa. INA Newsl., 4:7-50.

1982b. Bibliography and taxa. INA Newsl., 4:65-96.

LaBrecque, J. L., Ciesielski, P. F., and Clement, B., 1987. Ocean Drilling Program, Leg 114 prospectus, subantarctic South Atlantic. ODP Sci. Prospectus, 14:1-135.

Loeblich, A. R., and Tappan, H., 1966. Annotated index and bibliography of the calcareous nannoplankton. Phycologia, 5:81-215.

1968. Annotated index and bibliography of the calcareous nannoplankton II. J. Paleontol., 42:584-598.

1969. Annotated index and bibliography of the calcareous nannoplankton III. J. Paleontol., 43:568-588.

1970a. Annotated index and bibliography of the calcareous nannoplankton IV. J. Paleontol., 44:558-574.

$1970 \mathrm{~b}$. Annotated index and bibliography of the calcareous nannoplankton V. Phycologia, 9:157-174.

1971. Annotated index and bibliography of the calcareous nannoplankton VI. Phycologia, 10:315-339.

1973. Annotated index and bibliography of the calcareous nannoplankton VII. J. Paleontol., 47:715-759.

Manivit, H., 1971. Les nannofossiles calcaires du Crétacé français (Aptien-Maestrichtien). Essai de biozonation appuyee sur les stratotypes [Ph.D. thesis]. Univ. Paris.

Martini, E., 1971. Standard Tertiary and Quaternary calcareous nannoplankton zonation. In Farinacci, A. (Ed.), Proc. 2nd Planktonic Conf. Roma, 1971, 2:739-785.

Mortimer, C. F., 1987. Upper Cretaceous calcareous nannofossil biostratigraphy of the southern Norwegian and Danish North Sea area. In Stradner, H., and Perch-Nielsen, K. (Eds.), Intern. Nannoplankton Assoc., Vienna Meeting 1985 Proc. Abh. Geol. Bundesanst. Austria, 39:1-315.

Perch-Nielsen, K., 1979. Calcareous nannofossils from the Cretaceous between the North Sea and the Mediterranean. In Aspekte der Kreide Europeas. Int. Union Geol. Sci. Ser. A, 6:223-272.

1985. Cenozoic calcareous nannofossils. In Bolli, H. M., Saunders, J. B., and Perch-Nielsen, K. (Eds.), Plankton Stratigraphy: Cambridge (Cambridge Univ. Press), 427-554.

Robaszynski, F., Bless, M.J.M., Felder, P.J.S., Foucher, J.-C., Legoux, O., Manivit, H., Meessen, J.P.M.T., and Van Der Tuuk, L. A., 1985. The Campanian-Maastrichtian boundary in the chalky facies close to the type-Maastrichtian area. Bull. Cent. Rech. S.N.E.A, 9:1-113.

Romein, A.J.T., 1979. Lineages in early Paleogene calcareous nannoplankton. Utrecht. Micropaleontol. Bull., 22:1-231.

Roth, P. H., 1978. Cretaceous nannoplankton biostratigraphy and oceanography of the northwestern Atlantic Ocean. In Benson, W. E., Sheridan, R. E., et al., Init. Repts. DSDP, 44: Washington (U.S. Govt. Printing Office), 731-760.

Sissingh, W., 1977. Biostratigraphy of Cretaceous calcareous nannoplankton. Geol. Mijnbouw, 56:37-65.

Steinmetz, J. C., 1983a. Bibliography and taxa of calcareous nannoplankton. INA Newsl., 5:4-13.

1983b. Bibliography and taxa of calcareous nannoplankton. INA Newsl., 5:29-47.

,1984a. Bibliography and taxa of calcareous nannoplanktonIII. INA Newsl., 6:6-37.

,1984b. Bibliography and taxa of calcareous nannoplanktonIV. INA Newsl., 6:55-81.

1985a. Bibliography and taxa of calcareous nannoplankton-V. INA Newsl., 7:5-28. 
, 1985b. Bibliography and taxa of calcareous nannoplanktonVI. INA Newsl., 7:122-145.

1986a. Bibliography and taxa of calcareous nannoplanktonVII. INA Newsl., 8:12-32.

1986b. Bibliography and taxa of calcareous nannoplanktonVIII. INA Newsl., 8:66-87.

1987a. Bibliography and taxa of calcareous nannoplanktonIX. INA Newsl., 9:6-29.

1987b. Bibliography and taxa of calcareous nannoplankton-X. INA Newsl., 9:81-109.

1988a. Bibliography and taxa of calcareous nannoplanktonXI. INA Newsl., 10:7-28.

1988b. Bibliography and taxa of calcareous nannoplanktonXII. INA Newsl., 10:60-88.

Thierstein, H. R., Geitzenauer, K. R., Molfino, B., and Shackleton, N. J., 1977. Global synchroniety of late Quaternary coccolith datum levels: validation by oxygen isotopes. Geology, 5:400-404.

Varol, O., 1989. Palaeocene calcareous nannofossil biostratigraphy. In Crux, J. A., and van Heck, S. E. (Eds.), Nannofossils and their Applications: Chichester (Ellis Horwood), 267-310.

Wei, W., and Wise, S. W., 1989. Paleogene calcareous nannofossil magnetobiochronology. Results from South Atlantic DSDP Site 516. Mar. Micropaleontol., 14:119-152.

Wind, F. H., 1979. Maestrichtian-Campanian nannofloral provinces of the southern Atlantic and Indian oceans. In Talwani, M., Hay, W. W., and Ryan, W.B.F. (Eds.), Deep Sea Drilling Results in the Atlantic Ocean. Continental Margins and Paleoenvironment. Am. Geophys. Union, Maurice Ewing. Ser., 3:123-137.

Wind, F. H., and Wise, S. W., 1983. Correlation of upper Campanian-lower Maestrichtian calcareous nannofossil assemblages in drill and piston cores from the Falkland Plateau, southwest Atlantic Ocean. In Ludwig, W. J., Krasheninnikov, V. A., et al., Init. Repts. DSDP, 71: Washington (U.S. Govt. Printing Office), 551-563.

Wise, S. W., 1983. Mesozoic and Cenozoic calcareous nannofossils recovered by Deep Sea Drilling Project Leg 71 in the Falkland Plateau region, southwest Atlantic Ocean. In Ludwig, W. J., Krasheninnikov, V. A., et al., Init. Repts. DSDP, 71: Washington (U.S. Govt. Printing Office), 481-550.

Wise, S. W., and Constans, R. E., 1976. Mid-Eocene planktonic correlations: northern Italy-Jamaica, W.I. Trans. Gulf Coast Assoc. Geol. Soc., 26:144-155.

Wise, S. W., and Wind, F. H., 1977. Mesozoic and Cenozoic calcareous nannofossils recovered by DSDP Leg 36 drilling on the Falkland Plateau, southwest Atlantic sector of the Southern Ocean. In Barker, P., Dalziel, I.W.D., et al., Init. Repts. DSDP, 36: Washington (U.S. Govt. Printing Office), 269-492.

Worsley, T. R., and Martini, E., 1970. Late Maastrichtian nannoplankton provinces. Nature, 225:1242-1243.

Date of initial receipt: 2 May 1989

Date of acceptance: 19 December 1989

Ms 114B-123

\section{APPENDIX}

\section{Calcareous Nannofossils Considered in this Chapter}

\section{Mesozoic}

Phanulithus additus Wind and Wise in Wise and Wind, 1977

Helicolithus anceps (Górka, 1957) Noël, 1970

Cretarhabdus angustiforatus (Black, 1971) Bukry, 1973

Reinhardtites anthophorus (Deflandre, 1959) Perch-Nielsen, 1968

Reinhardtites aff. $R$. anthophorus sensu Prins and Sissingh in Sissingh, 1977

Lucianorhabdus arborius Wind and Wise in Wise and Wind, 1977 Lucianorhabdus arcuatus Forchheimer, 1972

Orastrum asarotrum Wind and Wise in Wise and Wind, 1977

Centosphaera barbata Wind and Wise in Wise and Wind, 1977

Watznaueria barnesae (Black in Black and Barnes, 1959) PerchNielsen, 1968

Cylindralithus biarcus Bukry, 1969

Watznaueria biporta Bukry, 1969

Calculites Prins and Sissingh in Sissingh, 1977
Orastrum campanensis (Čepek, 1970) Wind and Wise in Wise and Wind, 1977

Boletuvelum candens Wind and Wise in Wise and Wind, 1977

Lithraphidites carniolensis Deflandre, 1963

Lucianorhabdus cayeuxii Deflandre, 1959

Glaukolithus compactus (Bukry, 1969) Perch-Nielsen, 1984

Cretarhabdus conicus Bramlette and Martini, 1964

Biscutum coronum Wind and Wise in Wise and Wind, 1977

Nephrolithus corystus Wind, 1983

Cretarhabdus crenulatus Bramlette and Martini, 1964

Prediscosphaera cretacea (Arkhangelsky, 1912) Gartner, 1968

Arkhangelskiella cymbiformis Vekshina, 1959

Microrhabdulus decoratus Deflandre, 1959

Biscutum dissimilis Wind and Wise in Wise and Wind, 1977

Cribrosphaera ehrenbergii Arkhangelsky, 1912

Biscutum ellipticum (Górka, 1957) Grun in Grun and Allemann, 1975

Broinsonia enormis (Shumenko, 1968) Manivit, 1971

Teichorhabdus ethmos Wind and Wise in Wise and Wind, 1977

Eiffellithus eximius (Stover, 1966) Perch-Nielsen, 1968

Lithastrinus floralis Stradner, 1962

Nephrolithus frequens Górka, 1957

Marthasterites furcatus (Deflandre in Deflandre and Fert, 1954) Deflandre, 1959

Tranolithus gabalus Stover, 1966

Quadrum gartneri Prins and Perch-Nielsen in Manivit, PerchNielsen, Prins, and Verbeek, 1977

Ottavianus giannus Risatti, 1973

Lithastrinus grillii Stradner, 1962

Reinhardtites levis Prins and Sissingh in Sissingh, 1977

Lucianorhabdus Deflandre, 1959

Kamptnerius magnificus Deflandre, 1959

Biscutum magnum Wind and Wise in Wise and Wind, 1977

Micula Vekshina, 1959

Staurolithites mielnicensis (Gorka, 1957) Perch-Nielsen, 1968

Micula murus (Martini, 1961) Bukry, 1973

Gartnerago obliquum (Stradner, 1963) Noël, 1970

Calculites obscurus (Deflandre, 1959) Prins and Sissingh in Sissingh, 1977

Ahmuellerella octoradiata (Górka, 1957) Reinhardt, 1964

Tranolithus orionatus (Reinhardt, 1966) Reinhardt, 1966

Watznaueria ovata Bukry, 1969

Broinsonia parca (Stradner, 1963) Bukry, 1969

Monomarginatus pectinatus Wind and Wise in Wise and Wind, 1977

Manivitella pemmatoidea (Deflandre in Manivit, 1965) Thierstein, 1971

Seribiscutum primitivum (Thierstein, 1974) Filewicz, Wind, and Wise in Wise and Wind, 1977

Monomarginatus primus $\mathrm{n}$. sp.

Monomarginatus quaternarius Wind and Wise in Wise and Wind, 1977

Scampanella Forchheimer and Stradner, 1973

Acuturris scotus (Risatti, 1973) Wind and Wise in Wise and Wind, 1977

Cylindralithus sculptus Bukry, 1969

Broinsonia signata (Noël, 1969) Noël, 1970

Pharus simulacrum Wind and Wise in Wise and Wind, 1977

Zeugrhabdotus sisyphus (Gartner, 1968) Crux, 1989

Arkhangelskiella specillata Vekshina, 1959

Zygodiscus spiralis Bramlette and Martini, 1964

Micula staurophora (Gardet, 1955) Stradner, 1963

Prediscosphaera stoveri (Perch-Nielsen, 1968) Shafik and Stradner, 1971

Microrhabdulus stradneri Bramlette and Martini, 1964

Thoracosphaera Kamptner, 1927

Helicolithus trabeculatus (Górka, 1957) Verbeek, 1977

Eiffellithus turriseiffeli (Deflandre in Deflandre and Fert, 1954) Reinhardt, 1965

Pervilithus varius Crux, 1981

Cenozoic

Cyclicargolithus abisectus (Müller, 1970) Wise, 1973

Discoaster adamanteus Bramlette and Wilcoxon, 1967

Zygodiscus adamas Bramlette and Sullivan, 1961 
Chiasmolithus altus Bukry and Percival, 1971

Amaurolithus Gartner and Bukry, 1975

Markalius apertus Perch-Nielsen, 1979

Discoaster barbadiensis Tan, 1927

Chiasmolithus bidens (Bramlette and Sullivan, 1961) Hay and Mohler, 1967

Braarudosphaera bigelowii (Gran and Braarud, 1935) Deflandre, 1947

Zygrhablithus bijugatus (Deflandre in Deflandre and Fert, 1954) Deflandre, 1959

Discoaster binodosus Martini, 1958

Reticulofenestra bisecta (Hay, Mohler, and Wade, 1966) Roth, 1970

Prinsius bisulcus (Stradner, 1963) Hay and Mohler, 1967

Tribrachiatus bramlettei (Bronnimann and Stradner, 1960) Proto Decima, Roth, and Todesco, 1975

Discoaster brouweri Tan, 1927 emend. Bramlette and Riedel, 1954

Chiphragmalithus calathus Bramlette and Sullivan, 1961

Chiasmolithus californicus (Sullivan, 1964) Hay and Mohler, 1967

Chiasmolithus Hay, Mohler, and Wade, 1966

Cribrocentrum coenurum (Reinhardt, 1966) Perch-Nielsen, 1971

Neochiastozygus concinnus (Martini, 1961) Perch-Nielsen, 1971

Chiasmolithus consuetus (Bramlette and Sullivan, 1961) Hay and Mohler, 1967

Tribrachiatus contortus (Stradner, 1958) Bukry, 1972

Toweius crassus (Bramlette and Sullivan, 1961) Perch-Nielsen, 1984

Nannotetrina cristata (Martini, 1958) Perch-Nielsen, 1971

Chiasmolithus danicus (Brotzen, 1959) Hay and Mohler, 1967

Reticulofenestra daviesii (Haq, 1968) Haq, 1971

Discoaster deflandrei Bramlette and Riedel, 1954

Amaurolithus delicatus Gartner and Bukry, 1975

Reticulofenestra dictyoda (Deflandre in Deflandre and Fert, 1954) Stradner in Stradner and Edwards, 1968

Neochiastozygus digitosus Perch-Nielsen, 1971

Prinsius dimorphosus (Perch-Nielsen, 1969) Perch-Nielsen, 1977

Helicosphaera dinesenii Perch-Nielsen, 1971

Discoaster Tan, 1927

Neochiastozygus distentus (Bramlette and Sullivan, 1961) PerchNielsen, 1971

Ellipsolithus distichus (Bramlette and Sullivan, 1961) Sullivan, 1964

Neococcolithes dubius (Deflandre in Deflandre and Fert, 1954) Black, 1967

Toweius eminens (Bramlette and Sullivan, 1961) Perch-Nielsen, 1971

Helicosphaera euphratis Haq, 1966

Chiasmolithus expansus (Bramlette and Sullivan, 1961) Gartner, 1970

Cyclicargolithus floridanus (Roth and Hay in Hay, Mohler, Roth, Schmidt, and Boudreaux, 1967) Bukry, 1971

Coccolithus formosus (Kamptner, 1963) Wise, 1973

Sphenolithus furcatolithoides Locker, 1967

Toweius gammation (Bramlette and Sullivan, 1961) Romein, 1979

Chiasmolithus gigas (Bramlette and Sullivan, 1961) Radomski, 1968

Gephyrocapsa Kamptner, 1943

Rhabdosphaera gladius Locker, 1967

Chiasmolithus grandis (Bramlette and Riedel, 1954) Radomski, 1968

Biscutum harrissonii Varol, 1989

Helicosphaera Kamptner, 1954

Pyrocyclus hermosus Roth and Hay in Hay, Mohler, Roth, Schmidt and Boudreaux, 1967

Sphenolithus heteromorphus Deflandre, 1953

Reticulofenestra hillae Bukry and Percival, 1971

Emiliania huxleyi (Lohmann, 1902) Hay and Mohler in Hay, Mohler, Roth, Schmidt, and Boudreaux, 1967

Markalius inversus (Deflandre in Deflandre and Fert, 1954) Bramlette and Martini, 1964

Pyrocyclus inversus Hay and Towe, 1962

Neochiastozygus junctus (Bramlette and Sullivan, 1961) PerchNielsen, 1971
Heliolithus kleinpellii Sullivan, 1964

Discoaster kuepperi Stradner, 1959

Pseudoemiliania lacunosa (Kamptner, 1963) Gartner, 1969

Cruciplacolithus latipons Romein, 1979

Discoaster lodoensis Bramlette and Riedel, 1954

Cyclicargolithus luminis (Sullivan, 1965) Bukry, 1971

Calcidiscus macintyrei (Bukry and Bramlette, 1969) Loeblich and Tappan, 1978

Toweius magnicrassus (Bukry, 1971) Romein, 1979

Prinsius martinii (Perch-Nielsen, 1969) Haq, 1971

Discoaster mohleri Bukry and Percival, 1971

Sphenolithus moriformis (Bronnimann and Stradner, 1960) Bramlette and Wilcoxon, 1967

Discoaster multiradiatus Bramlette and Riedel, 1954

Neochiastozygus Perch-Nielsen, 1971

Chiasmolithus oamaruensis (Deflandre in Deflandre and Fert, 1954) Hay, Mohler, and Wade, 1966

Reticulofenestra oamaruensis (Deflandre in Deflandre and Fert, 1954) Stradner in Haq, 1968

Thoracosphaera operculata Bramlette and Martini, 1964

Tribrachiatus orthostylus Shamrai, 1963

Coccolithus pelagicus (Wallich, 1877) Schiller, 1930

Discoaster pentaradiatus Tan, 1927 emend. Bramlette and Riedel, 1954

Reticulofenestra perplexa (Burns, 1975) Wise, 1983

Toweius pertusus (Sullivan, 1965) Romein, 1979

Cruciplacolithus primus Perch-Nielsen, 1977

Calcidiscus protoannulus (Gartner, 1971) Loeblich and Tappan, 1978

Neococcolithes protenus (Bramlette and Sullivan, 1961) Black, 1967

Sphenolithus pseudoradians Bramlette and Wilcoxon, 1967

Reticulofenestra pseudoumbilicus (Gartner, 1967) Gartner, 1969

Sphenolithus radians Deflandre in Grasse, 1952

Isthmolithus recurvus Deflandre in Deflandre and Fert, 1954

Cribrocentrum reticulatum (Gartner and Smith, 1967) Perch-Nielsen, 1971

Heliolithus riedelii Bramlette and Sullivan, 1961

Neocrepidolithus rimosus (Bramlette and Sullivan, 1961) Varol, 1989

Discoaster robustus Haq, 1969

Discoaster saipanensis Bramlette and Riedel, 1954

Scampanella Forchheimer and Stradner 1973

Helicosphaera seminulum Bramlette and Sullivan, 1961

Helicosphaera sellii Bukry and Bramlette, 1969

Placozygus sigmoides (Bramlette and Sullivan, 1961) Romein, 1979

Chiasmolithus solitus (Bramlette and Sullivan, 1961) Locker, 1968

Sphenolithus Deflandre in Grasse, 1952

Blackites spinosus (Deflandre in Deflandre and Fert, 1954) Hay and Towe, 1962

Clausicoccus subdistichus (Roth and Hay, 1967) Prins, 1979

Discoaster sublodoensis Bramlette and Sullivan, 1961

Coccolithus subpertusus (Hay and Mohler, 1967) Van Heck and Prins, 1987

Discoaster surculus Martini and Bramlette, 1963

Discoaster tani nodifer Bramlette and Riedel, 1954

Cruciplacolithus tenuis (Stradner, 1961) Hay and Mohler in Hay, Mohler, Roth, Schmidt, and Boudreaux, 1967

Hornibrookina teuriensis Edwards, 1973

Thoracosphaera Kamptner, 1927

Chiasmolithus titus Gartner, 1970

Toweius tovae Perch-Nielsen, 1971

Amaurolithus tricorniculatus (Gartner, 1967) Gartner and Bukry, 1975

Fasciculithus tympaniformis Hay and Mohler in Hay, Mohler, Roth, Schmidt, and Bordreaux, 1967

Reticulofenestra umbilicus (Levin, 1965) Martini and Ritzkowski, 1968

Cruciplacolithus vanheckiae Perch-Nielsen, 1984

Discoaster wemmelensis Achuthan and Stradner, 1969 